University of Nebraska - Lincoln

DigitalCommons@University of Nebraska - Lincoln

Roman L. Hruska U.S. Meat Animal Research

U.S. Department of Agriculture: Agricultural Center

Research Service, Lincoln, Nebraska

$1-1-2021$

\title{
Environmental conditions and gas concentrations in deep-pit finishing cattle facilities: A descriptive study
}

\author{
Erin L. Cortus \\ University of Minnesota Twin Cities, ecortus@umn.edu \\ Brian P. Hetchler \\ University of Minnesota Twin Cities \\ Mindy J. Spiehs \\ USDA-ARS, U.S. Meat Animal Research Center, mindy.spiehs@ars.usda.gov \\ Warren Rusche \\ South Dakota State University, SDSU Extension, warren.rusche@sdstate.edu
}

Follow this and additional works at: https://digitalcommons.unl.edu/hruskareports

Part of the Animal Sciences Commons

Cortus, Erin L.; Hetchler, Brian P.; Spiehs, Mindy J.; and Rusche, Warren, "Environmental conditions and gas concentrations in deep-pit finishing cattle facilities: A descriptive study" (2021). Roman L. Hruska U.S. Meat Animal Research Center. 569.

https://digitalcommons.unl.edu/hruskareports/569

This Article is brought to you for free and open access by the U.S. Department of Agriculture: Agricultural Research Service, Lincoln, Nebraska at DigitalCommons@University of Nebraska - Lincoln. It has been accepted for inclusion in Roman L. Hruska U.S. Meat Animal Research Center by an authorized administrator of DigitalCommons@University of Nebraska - Lincoln. 


\title{
ENVIRONMENTAL CONDITIONS AND GAS CONCENTRATIONS IN DEEP-PIT FINISHING CATTLE FACILITIES: A DESCRIPTIVE STUDY
}

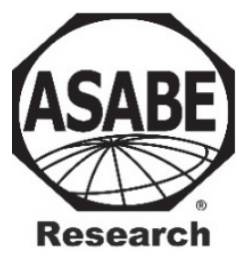

\author{
E. L. Cortus, B. P. Hetchler, M. J. Spiehs, W. C. Rusche
}

\section{HighLIGHTS}

- Temperature and air movement in the naturally ventilated barns correlated to ambient conditions.

- Manure N-P-K values related to solids distribution in the manure storage.

- Ammonia and combined sulfur concentrations increased with closer proximity to the manure surface.

- Influences of manure properties, airflow conditions, barn design, and management were evident for gas concentrations.

ABSTRACT. There is a lack of data to describe the range of environmental and air quality conditions in beef cattle confinement buildings with deep-pit manure storage. The objective of this article is to describe the environmental conditions, manure nutrient concentrations, and aerial gas concentrations for three deep-pit manure storage finishing beef cattle facilities and varying weather conditions. Measurements were collected from three barns finishing beef cattle with deep pits in Minnesota on three sampling days per barn in summer, fall, and spring weather conditions. The air temperatures throughout the barns closely mirrored the ambient temperature conditions, although significantly lower temperatures were sometimes evident at the manure surface or in the inlet opening. However, the manure and floor surfaces had $2^{\circ} \mathrm{C}$ and $5^{\circ} \mathrm{C}$ temperature increases over ambient temperatures. Air speeds through the barn openings were generally $40 \%$ of the ambient wind speed; at animal level, the average air speed was 1 to $3 \mathrm{~m} \mathrm{~s}^{-1}$. Manure nutrient distributions were not consistent between the surface and agitated (whole pit) samples, and this was likely due in part to solids distribution in the storage. Total nitrogen levels ranged from 4.5 to $6.7 \mathrm{~g} \mathrm{~L}^{-1}$, and ammonium- $N$ was $50 \%$ to $65 \%$ of total $N$ in agitated whole-pit samples. Phosphate and potassium oxide levels ranged from 2.8 to $4.2 \mathrm{~g} \mathrm{~L}^{-1}$ and from 3.7 to $4.5 \mathrm{~g} \mathrm{~L}^{-1}$, respectively. Aerial ammonia and combined sulfur concentrations varied by location within a barn, pen, and season. Ammonia and combined sulfur increased with proximity to the manure surface. Higher ammonia and combined sulfur concentrations at manure level and floor level for one of the three barns may have related to water quality and/or feed composition and resulting manure nutrients, in addition to warmer temperatures. At floor level, the greatest average ammonia concentration was $8.5 \mathrm{ppm}$, and $3.9 \mathrm{ppm}$ at nose level. Maximum combined sulfur levels were a maximum of $270 \mathrm{ppb}$ at floor level in summer conditions in one of the barns, while 52 ppb was the maximum average during spring conditions. Carbon dioxide levels also varied by location within a barn, pen, and season and were related in part to the presence of cattle in the pen. This project is the first to quantify air quality in slatted-floor cattle barns and contributes to a body of knowledge that can be used to develop process-based models for estimating air emissions from cattle facilities.

Keywords. Airflow, Ammonia, Beef cattle, Confinement, Hydrogen sulfide, Manure characteristics, Temperature.

Submitted for review on 10 April 2020 as manuscript number PAFS 14040; approved for publication as a Research Article by the Plant, Animal, \& Facility Systems Community of ASABE on 25 August 2020.

Mention of company or trade names is for description only and does not imply endorsement by the USDA. The USDA is an equal opportunity provider and employer.

The authors are Erin L. Cortus, Associate Professor and Extension Engineer, and Brian P. Hetchler, Researcher, Department of Bioproducts and Biosystems Engineering, University of Minnesota, St. Paul, Minnesota; Mindy J. Spiehs, Research Animal Scientist, USDA-ARS U.S. Meat Animal Research Center, Clay Center, Nebraska; Warren C. Rusche, Extension Beef Feedlot Management Associate, Department of Animal Science, South Dakota State University, Brookings, South Dakota. Corresponding author: Erin Cortus, 1390 Eckles Ave., St. Paul, MN 55108; phone: 612-625-8288; e-mail: ecortus@umn.edu.

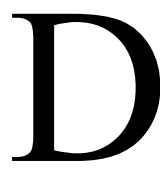
eep-pit cattle facilities are increasing in number in the U.S. Midwest and northern Great Plains. Local Extension and USDA Natural Resources Conservation Service (USDA-NRCS) personnel estimate that $50 \%$ to $60 \%$ of new confinement barns under construction in the region have deep-pit manure storage under slatted floors (J. Bonnema, USDA-NRCS, personal communication, Dec. 19, 2019; K. Kohl, ISU Extension, personal communication, Dec. 19, 2019). Anecdotally, producers cite regulatory compliance, lighter workload, increased manure value, and better beef cattle efficiency as reasons for building deep-pit barns compared to open-lot or beddedpack confinement barns (Johnston, 2015). Facility investments are being made in spite of relatively little published information regarding how management practices, weather 
conditions, and facility characteristics interact to affect cattle performance, air quality, and manure value in naturally ventilated, deep-pit cattle facilities. In addition, cattle feeders contemplating constructing these facilities often are faced with concerns from external stakeholders about odor and environmental risks arising from animal confinement facilities.

Deep-pit manure storage results in different aerial nutrient losses and manure value compared to solid manure storage and handling. Assuming a density of $1 \mathrm{t} \mathrm{m}^{-3}$ for liquid manure, literature values for finishing beef cattle liquid manure systems are $3.5,1.0,2.2$, and $3.1 \mathrm{~kg} \mathrm{t}^{-1}$ for total nitrogen $(\mathrm{N})$, ammonium-nitrogen $\left(\mathrm{NH}_{4}-\mathrm{N}\right)$, phosphate $\left(\mathrm{P}_{2} \mathrm{O}_{5}\right)$, and potassium oxide $\left(\mathrm{K}_{2} \mathrm{O}\right)$, respectively. Liquid manure characteristics are lower than solid manure nutrient characteristics for finishing cattle, which are 5.5, 2.0,3.5, and $5.5 \mathrm{~kg} \mathrm{t}^{-1}$ (MWPS, 2004) for $\mathrm{N}, \mathrm{NH}_{4}-\mathrm{N}, \mathrm{P}_{2} \mathrm{O}_{5}$, and $\mathrm{K}_{2} \mathrm{O}$, respectively. Nitrogen losses from manure packs or daily scrape-and-haul management systems range from $25 \%$ to $30 \%$, while underfloor liquid loses only $20 \%$ of $\mathrm{N}$ during storage (Sutton et al., 2001). Ammonia $\left(\mathrm{NH}_{3}\right)$ emission during a 250 -day storage period were greater for solid beef manure $(49 \%$ of the $\mathrm{NH}_{4}-\mathrm{N}$ in the stored manure) than for liquid beef manure (12\% of the $\mathrm{NH}_{4}-\mathrm{N}$ in the stored manure) (Balsdon et al., 2000). Similarly, swine facilities with deep-litter manure storage systems had significantly greater daily $\mathrm{NH}_{3}(110 \%)$, nitrous oxide $\left(\mathrm{N}_{2} \mathrm{O} ; 105 \%\right)$, and carbon dioxide $\left(\mathrm{CO}_{2} ; 13 \%\right)$ emissions compared to swine facilities with slatted floors and underground pits (Philippe et al., 2007).

Environmental conditions inside cattle confinement barns are expected to vary diurnally and by season due to the influences of ambient temperature and cattle behavior. In naturally ventilated monoslope facilities, ambient temperatures ranged from an average of $-2.8^{\circ} \mathrm{C}$ during winter to a high of $23.9^{\circ} \mathrm{C}$ during summer (Spiehs et al., 2011). Producers have long known that cattle are most active between 6:00 a.m. and 6:00 p.m., and the diurnal feeding pattern is very consistent (Ray and Roubicek, 1971), with peak feeding in late morning and late afternoon (Gibb et al., 1998). Seasonal temperature fluctuations also affect animal activity, which in turn affects gas emissions. Ngwabie et al. (2011) reported that daily $\mathrm{NH}_{3}$ emissions increased significantly as indoor air temperatures increased in naturally ventilated dairy barns. Additionally, they reported that daily methane $\left(\mathrm{CH}_{4}\right)$ emissions increased significantly with animal activity, and that $\mathrm{CH}_{4}$ emissions were negatively correlated with indoor air temperature, which suggested that animal activity decreased when indoor air temperature increased (Ngwabie et al., 2011).

Natural ventilation tends to move considerable amounts of air through beef cattle confinement facilities, reducing aerial gas concentrations. Previous research measured 33 air changes per hour $(\mathrm{ACH})$ when the north wall curtains on naturally ventilated monoslope barns were open, but only 7 $\mathrm{ACH}$ when the curtains were closed (Cortus et al., 2015). Average $\mathrm{NH}_{3}$ and hydrogen sulfide $\left(\mathrm{H}_{2} \mathrm{~S}\right)$ concentrations increased as airflow through naturally ventilated monoslope barns decreased, with maximum $\mathrm{NH}_{3}$ and $\mathrm{H}_{2} \mathrm{~S}$ concentrations of $4 \mathrm{ppm}$ and $200 \mathrm{ppb}$, respectively (Cortus et al., 2014). Few studies have looked at concentrations at animal level or at aerial gas concentration and temperature distribu- tions in the animal zone, particularly with animal occupation. Reduced airflow rates and increased ammonia concentrations in power-ventilated barns were associated with poorer cattle performance during warm weather conditions (Morrison et al., 1976).

Models exist to estimate the flow of nutrients through barns, such as the Integrated Farm System Model (Rotz et al., 2012) and the Manure-DNDC (Li et al., 2012). These models simulate major farm components on a process level to generate whole-farm nutrient balances (IFSM), and carbon and nitrogen fluxes (Manure-DNDC). The more data available to these models, the better the models can be refined to evaluate manure management, crop production, and nutrient efficiencies for the range of beef cattle production systems across the U.S. (Asem-Hiablie et al., 2015, 2016, 2017, 2018). Production-scale manure and environmental data inform and validate model estimates, enabling systematic simulations of nutrient movement, as well as manure values between system types.

The objective of this article is to describe the environmental conditions, manure nutrient concentrations, and aerial gas concentrations for three deep-pit manure storage finishing beef cattle facilities and varying weather conditions.

\section{Methodology BARNS}

We worked with three producer-cooperators who own and manage deep-pit finishing cattle barns in Minnesota. We refer to the barns as barn F (fig. 1), barn H (fig. 2), and barn R (fig. 3). All three barns were oriented east-west. Barns F and $\mathrm{R}$ had a single row of pens, and barn $\mathrm{H}$ was a doublewide barn with a feed delivery alley down the middle of the barn. Barn $\mathrm{H}$ contained three sections: sections 1 and 3 had deep-pit manure storage, while section 2 had a working area and bedded pack pens for young cattle or cattle requiring more intensive monitoring or treatment. Each barn had at least four pens that shared a common airspace above the slatted floors. Multiple pens of cattle at each barn shared a common pit volume under the slotted floor (table 1, figs. 1 to 3). Barn F had equalizing holes in the concrete wall separating the two pit volumes. Barn $\mathrm{H}$ directed precipitation collected on the north side of the roof to the two pit volumes. All barns had mats covering the concrete slatted floor, with mat openings aligned with the slat openings. The mats were rubber at barns $F$ and $R$ and in pens 2 and 13 at barn H. In pens 6 and 9 at barn $\mathrm{H}$, the mats were an air-filled thermoplastic elastomeric material. All three barns used well water.

\section{Data Collection}

Data collection occurred in each barn for one day during summer (July), fall (September), and spring (March-April) conditions (three days total). We did not ask the producers to adjust their barn management activities and collected data based on the "as-is" situation. On each sampling day, measurements commenced after the morning feed delivery and cattle health check and required 6 to $9 \mathrm{~h}$ to complete. We collected three sets of measurements within and around the pens on each sampling day. In-pen sampling was done in 


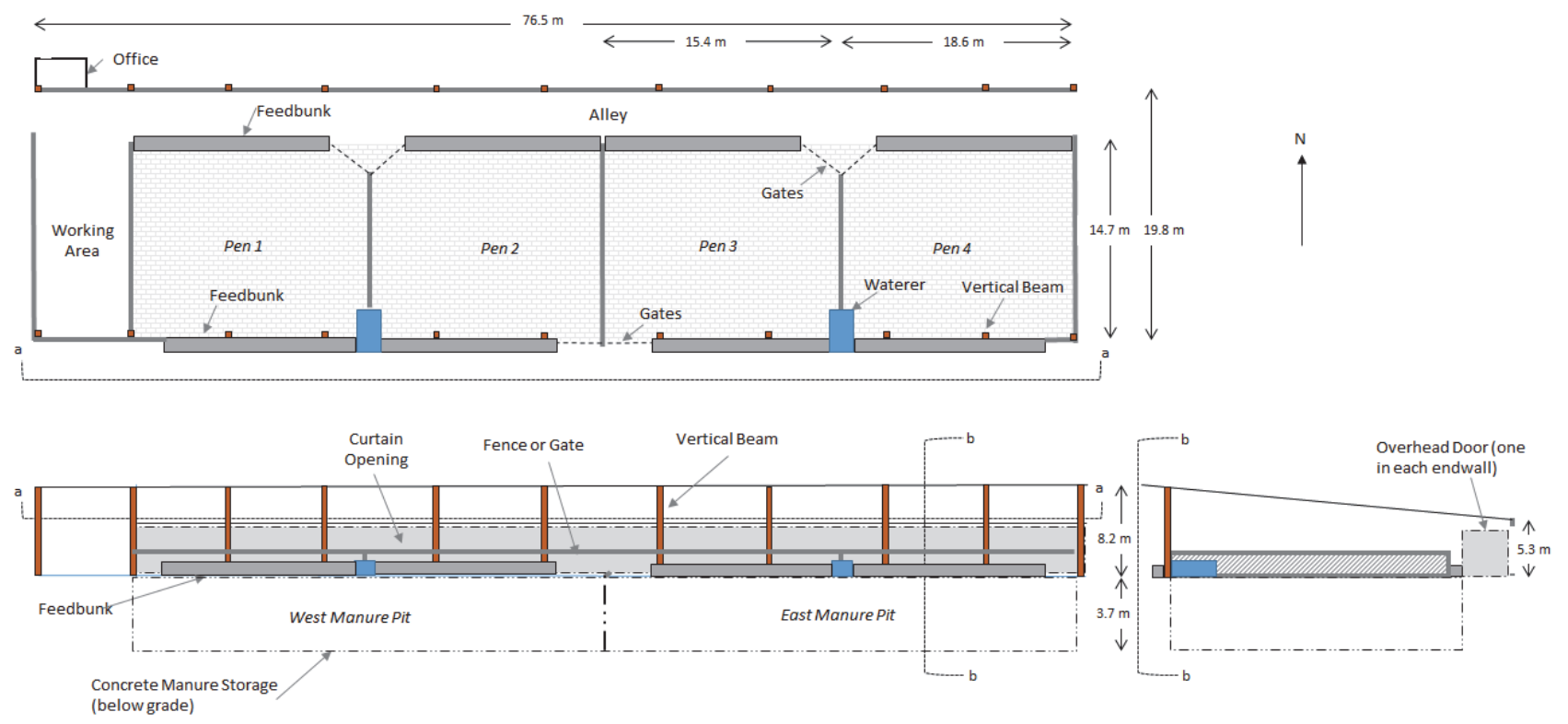

Figure 1. Plan (top left), front (bottom left), and side views (bottom right) of barn F (not to scale). Below grade, under the slatted floor of the pens, is the deep-pit manure storage.

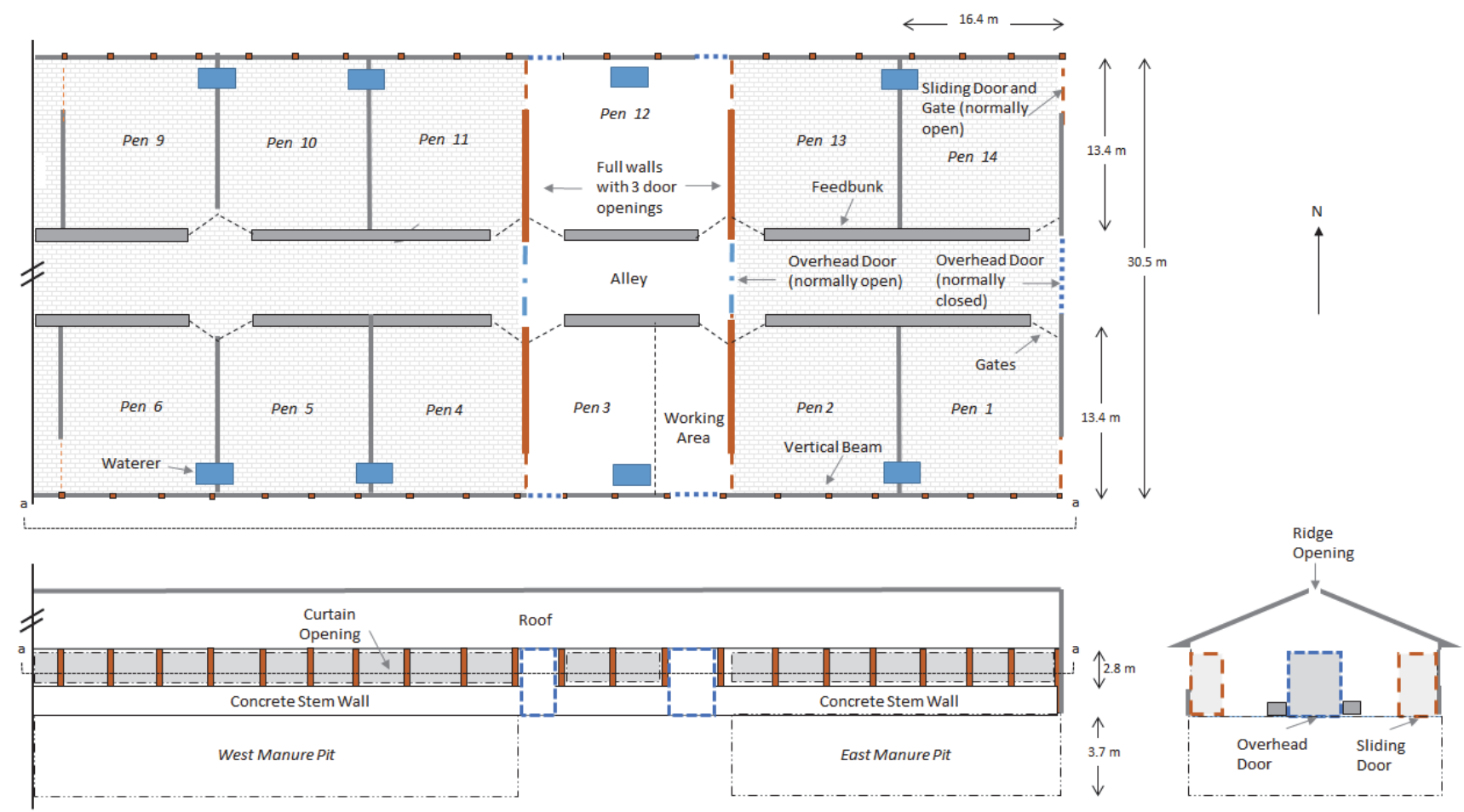

Figure 2. Plan (top left), front (bottom left), and side views (bottom right) of barn $\mathrm{H}$ (not to scale). There are additional pens (pens 7 to 10) beyond the left side of the plan and front views. Below grade, under the slatted floor of the pens, is the deep-pit manure storage.

pairs, so that one person could monitor cattle movements and behavior, and the second person could focus on instrumentation. We generally limited movements to the outer perimeter of each pen to reduce cattle disruption.

\section{Environmental Conditions}

Environmental conditions included conditions within the pens and around the barn perimeter. Within each pen, we carried a sampling apparatus to the four quadrants of the pen. We visited fewer quadrants in limited cases when the cattle expressed agitation to avoid researcher and animal injury.
The sampling apparatus supported a portable datalogger (UX120-014M, Onset Computer Corp., Bourne, Mass.) with a sampling frequency of $10 \mathrm{~s}$. Type-T thermocouples measured air temperature conditions at 15 to $30 \mathrm{~cm}$ above the manure surface (manure), $10 \mathrm{~cm}$ above the floor surface (floor), and $1 \mathrm{~m}$ above the floor surface (nose) in tandem with gas sample collection. The collocated gas samples (described in the Gas Concentrations section) provided humidity measurements via the dewpoint temperature measurement for each bag sample. 


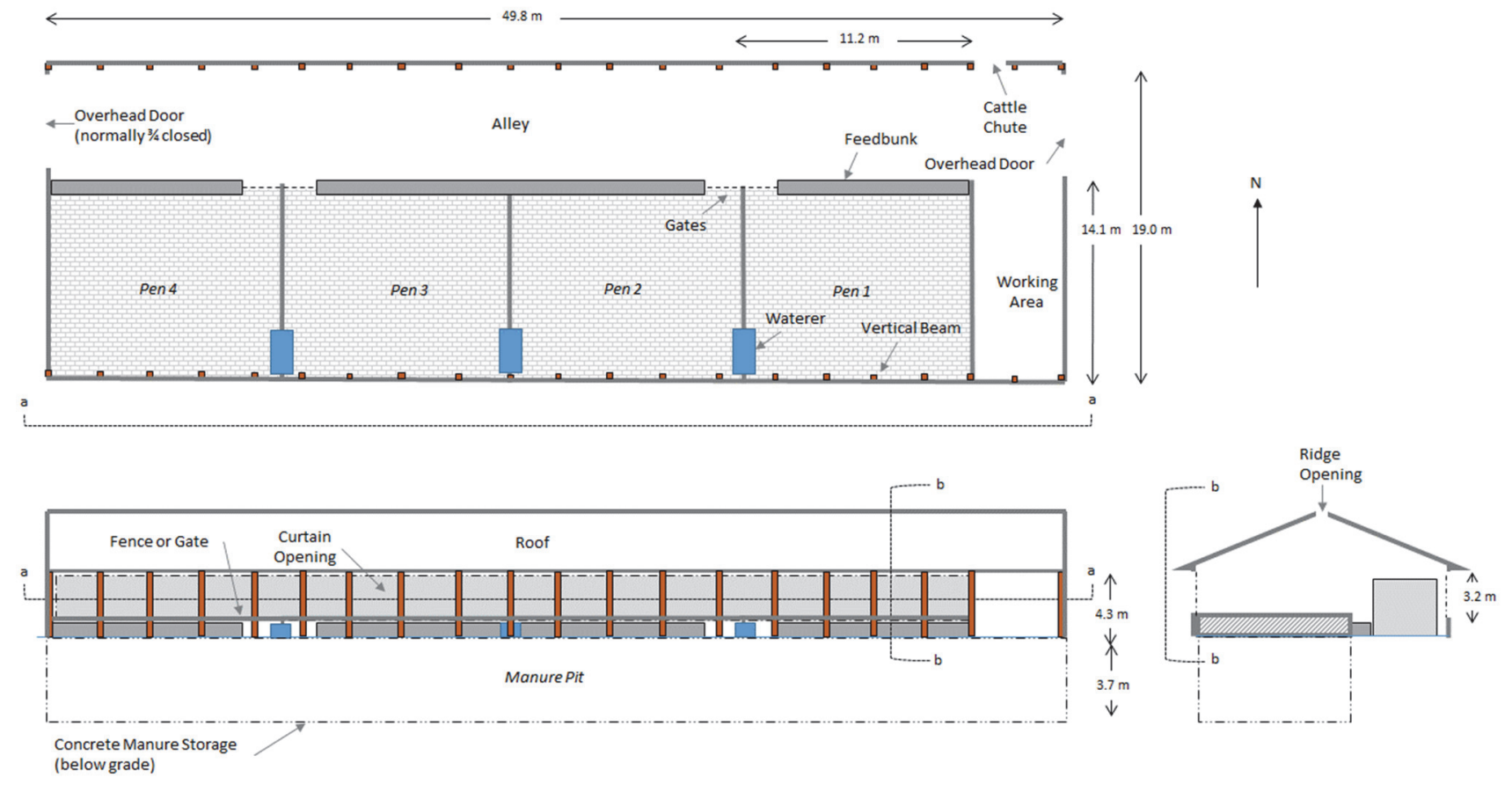

Figure 3. Plan (top left), front (bottom left), and side views (bottom right) of barn R (not to scale). Below grade, under the slatted floor of the pens, is the deep-pit manure storage.

Table 1. Characteristics of monitored deep-pit cattle barns in Minnesota.

\begin{tabular}{|c|c|c|c|}
\hline Characteristic & Barn F & Barn $\mathrm{H}$ & Barn R \\
\hline Barn dimensions (m) & $76.5 \times 19.8$ & $152.4 \times 30.5$ & $49.8 \times 19.0$ \\
\hline Pen dimensions $(\mathrm{m})$ & $\begin{array}{c}18.6 \times 14.7(\text { pens } 1 \text { and } 4) \\
\text { and } 15.4 \times 14.7(\text { pens } 2 \text { and } 3)\end{array}$ & $16.4 \times 13.4$ & $11.2 \times 14.1$ \\
\hline South wall opening height (m) & 8.2 & 2.8 & 4.3 \\
\hline North wall opening height $(\mathrm{m})$ & 5.3 & 2.8 & 3.2 \\
\hline Number of pens & 4 & 12 over deep pit; 2 bedded pack & 4 \\
\hline Pen capacity (head) & $\begin{array}{c}137 \text { (pens } 1 \text { and } 4) \\
\text { and } 112 \text { (pens } 2 \text { and } 3 \text { ) }\end{array}$ & 110 & 75 \\
\hline Barn capacity (head) & 500 & 1540 & 300 \\
\hline Number of deep pits & 2 & $2^{[a]}$ & 1 \\
\hline Pit depth $(\mathrm{m})$ & $3.7^{[b]}$ & 3.7 & 3.7 \\
\hline Equalizing holes between pits & Yes & No & $\mathrm{n} / \mathrm{a}$ \\
\hline Feed bunk location & $\mathrm{N}, \mathrm{S}$ & Center alley & $\mathrm{N}$ \\
\hline Roof type & Monoslope & Gable & Gable \\
\hline Curtains & $\mathrm{N}$ & $\mathrm{N}, \mathrm{S}$ & $\mathrm{N}$ \\
\hline
\end{tabular}

In tandem with the person moving and supporting the inpen sampling apparatus, a second person collected and manually recorded surface temperatures and air speeds in four quadrants per pen. Surface temperatures of the floor, manure surface, and roof underside, measured with an infrared gun (model 2267-20, Milwaukee Tools, Brookfield, Wisc.), were the average of multiple locations per quadrant. We recorded air speed measurements in the north-south plane and eastwest plane at cattle level in the pen, but cardinal direction was not determined. The air speed sensor (model 5000, Kestrel Meters, Boothwyn, Pa.) was at $1.6 \mathrm{~m}$ height and arm's length away from the project personnel to collect a $10 \mathrm{~s} \mathrm{av-}$ erage for each quadrant in both directions.

We placed temperature and relative humidity loggers (HOBO Pro v2, U23-001, Onset Computer Corp.), with a 10 $\mathrm{s}$ measurement frequency, in the center of the north and south openings. A radiation shield protected the south wall sensor. During the fall and spring measurement periods, a 3D sonic anemometer (model 81000, R.M. Young Co., Traverse City, Mich.) was temporarily installed in the north wall opening (barns F and R) or south wall opening (barn $\mathrm{H}$ ) of a central pen. A portable analog logger (UX120-006M, Onset Computer Corp.) recorded the wind speed and direction every $10 \mathrm{~s}$.

Local weather station data, including temperature, relative humidity, wind direction and speed, and sky conditions were obtained for the sampling days (Weather Underground, 2019). The frequency of measurements was less than $1 \mathrm{~h}$. The weather stations were approximately 19, 15, and 5 linear $\mathrm{km}$ from barns $\mathrm{F}, \mathrm{H}$, and $\mathrm{R}$, respectively.

\section{Manure, Feed, and Water}

Manure depth was based on the measured distance from the top of the slatted floor to the top of the manure surface at 
the start of each sampling day using multiple measurements per pen.

Water samples collected on each farm were from the same source supplying the cattle drinking water. Water samples were frozen prior to anion analysis (fluoride, chloride, $\mathrm{N}$ as nitrate, bromide, $\mathrm{N}$ as nitrate, sulfate, $\mathrm{P}$ as phosphate) by the University of Minnesota Earth Sciences Laboratory using ion chromatography (Thermo Dionex ICS 5000+, ThermoFisher Scientific, Waltham, Mass.).

Aggregated grab feed samples for each feed formulation delivered at each farm on the sampling day were frozen while in storage prior to analysis; the barn F fall sample was missed. The University of Wisconsin (UW) Soil and Forage Analysis Laboratory performed total mixed ration quality control analyses (wet chemistry dry matter, crude protein, ash, neutral detergent fiber digestibility [NDFD], neutral detergent fiber [NDF], $\mathrm{Ca}, \mathrm{P}, \mathrm{Mg}, \mathrm{K}$, and fat) and wet chemistry total mineral analyses $(\mathrm{P}, \mathrm{Ca}, \mathrm{K}, \mathrm{Mg}, \mathrm{Na}, \mathrm{S}, \mathrm{Fe}, \mathrm{Mn}, \mathrm{Zn}$, and $\mathrm{Cu}$ ) on each sample. The laboratory methods are detailed by Peters (2013).

At the end of each sampling day, we used a custom-made sampler to collect surface manure through the slatted floor. The sampler consisted of two emptied and cleaned ice packs, with the tops removed, attached to a PVC tube with sufficient length to reach approximately $20 \mathrm{~cm}$ below the surface of the manure, yet slim enough $(23 \mathrm{~cm} \times 3 \mathrm{~cm})$ to fit through the slatted floor or mat openings $(24 \mathrm{~cm} \times 4 \mathrm{~cm})$. At multiple locations within a pen, the sampler was gently pushed through the crust (if present) and manure surface until the sampler container height $(14 \mathrm{~cm})$ was submerged, and manure could spill in to fill the $700 \mathrm{~mL}$ container. We did not compensate for or equalize the amount of crust in samples but instead tried to sample a consistent liquid depth. The manure collected at multiple locations in a pen was mixed to create a composite sample for each pen, which was stored in a freezer prior to analysis. The UW Soil and Forage Analysis Laboratory analyses of each manure sample included dry matter, total nitrogen, total phosphorus as phosphate $\left(\mathrm{P}_{2} \mathrm{O}_{5}\right)$, total potassium as potassium oxide $\left(\mathrm{K}_{2} \mathrm{O}\right)$, sulfur, ammonium-nitrogen $\left(\mathrm{NH}_{4}-\mathrm{N}\right)$ and ash, using methods described by Peters (2013).

\section{Gas Concentrations}

In conjunction with air temperature monitoring, the sampling apparatus supported three personal sampling pumps for in-pen gas sample collection. The sampling pumps (224PCXR4, SKC Inc., Eighty Four, Pa.) pulled air from approximately 15 to $30 \mathrm{~cm}$ above the manure surface (manure), $10 \mathrm{~cm}$ above the floor surface (floor), and $1 \mathrm{~m}$ above the floor surface (nose) through Teflon tubing and pushed the air samples into 10 L Tedlar bags (232-08, SKC Inc.). The pump flow rates were set at $2 \mathrm{~L} \mathrm{~min}^{-1}$; measurements required approximately 2 min in each quadrant and $8 \mathrm{~min}$ total in each pen.

We strung two Teflon sampling lines at equidistant points in the middle of the openings on the north and south sides of each pen (out of reach of the cattle) (barns F and R) or set of pens (barn H; pens 2 and 13 and pens 6 and 9). These samples are referred to as the north wall and south wall samples. We teed the lines together and pulled air into a vacuum chamber (Vac-U-chamber, SKC Inc.). The pump flow rate was approximately $1 \mathrm{~L} \mathrm{~min}^{-1}$. Sampling start and finish coincided with the start and finish of pen sampling, approximately $8 \mathrm{~min}$.

Bagged air samples were analyzed immediately on-site for gas concentrations. A photoacoustic infrared multi-gas monitor (Innova 1412, Innova Air Tech Instruments, Ballerup, Denmark) measured ammonia $\left(\mathrm{NH}_{3}\right), \mathrm{CO}_{2}$, and dewpoint temperature. A pulsed fluorescence analyzer (TEC 450i, Thermo Electron Corp., Franklin, Mass.) measured combined sulfur, which is the combination of sulfur dioxide $\left(\mathrm{SO}_{2}\right)$ and $\mathrm{H}_{2} \mathrm{~S}$. We allowed a minimum 3 min response time for the analyzers' measurements to stabilize with each new bag and recorded three consecutive measurements over a period of $2.5 \mathrm{~min}$ for each gas to produce the average reported concentration for each bag. Between sampling periods, we purged the bags with zero air using a zero air generator (model 701, Teledyne API, San Diego, Cal.) and randomly verified that no trace residue was left in the bags following purging. The manufacturer-specified minimum detection limits were $0.2 \mathrm{ppm}, 5 \mathrm{ppm}$, and $2 \mathrm{ppb}$ for $\mathrm{NH}_{3}, \mathrm{CO}_{2}$, and combined sulfur, respectively. We verified the gas analyzer response against standard gases (zero gas, $10 \mathrm{ppm} \mathrm{NH}_{3}$, $1300 \mathrm{ppm} \mathrm{CO}_{2}$, and $1000 \mathrm{ppb} \mathrm{H}_{2} \mathrm{~S}$ ) after each season. The Innova 1412 was manufacturer-calibrated to compensate for potential cross-interferences between gases normally present in cattle barns.

Sampling of volatile organic compounds (VOCs) was performed in conjunction with the last measurement period on each sampling day during the summer and fall sampling periods. We used the air collected in the Tedlar bags for a central pen at nose level, and the corresponding windward wall sample. Duplicate samples were collected in pre-conditioned stainless steel sorbent tubes $(89 \times 6.4 \mathrm{~mm}$ OD, Markes International, Wilmington, Del.) packed with 200 mg Tenax TA sorbent. Using a vacuum pump (Pocket Pump 210 Series, SKC Inc.), air was pulled from the Tedlar bags through a sorbent tubes at a rate of $178 \mathrm{~mL} \mathrm{~min}^{-1}$ for $10 \mathrm{~min}$. Duplicated sample values were averaged by location and date. The sorbent tubes were analyzed using a thermal desorption-gas chromatograph-mass spectrometry (TD-GCMS) system described by Parker et al. (2013). The analysis system consisted of thermal desorption with a Unity 2 (Markes International, Cincinnati, Ohio) with an autosampler (Ultra 2, Markes International) and a GC-MS (7890A/5975C, Agilent Technologies, Santa Clara, Cal.). The sorbent tubes were analyzed for seven volatile fatty acids (acetic acid, propionic acid, butyric acid, isobutyric acid, valeric acid, isovaleric acid, and hexanoic acid), five aromatic compounds (phenol, p-cresol, 4-ethylphenol, indole, and skatole), and two sulfide compounds (dimethyldisulfide and dimethyltrisulfide). Parker et al. (2013) described the calibration and method detection limit calculations.

\section{Cattle Information}

The cooperating producers provided the following supporting data: (1) number of animals per pen, (2) approximate weight, (3) feed intake, and (4) any cattle movements, manure removal, or water addition activities in the week preceding monitoring. The producers also collected manure samples during their manure removal and land-application 
activities that represent average manure characteristics for the manure pit or storage. The agitated samples were analyzed similar to the surface manure samples.

\section{Data Analysis}

For the surface and air temperatures and air velocities within a pen, we averaged the data across all pens and for the three sampling periods on a sampling day for further analysis and reporting by location.

For gas concentrations, dry-bulb temperatures, and dewpoint temperatures, we averaged the data for the three sampling periods on a sampling day by location within a pen for further analysis. Pen (four pens per barn), location (manure, floor, nose, north wall, south wall), season (summer, fall, spring), and their interactions were fixed treatment variables and were tested for significant effects with PROC GLIMMIX in SAS (ver. 9.4, SAS Institute, Cary, N.C.). A lognormal transformation for gas concentrations $\left(\mathrm{NH}_{3}\right.$, combined sulfur, and $\mathrm{CO}_{2}$ ) improved the distribution of residuals compared to a Gaussian distribution. Differences in least-square means with Tukey's adjustment are presented; data were back-transformed for presentation in this article.

For VOCs, all samples were averaged within barn or location for statistical analysis. Barn and location were treated as fixed treatment variables in the PROC MIXED analysis in SAS. When significant differences were detected, Fisher's least significant difference (LSD) test was used to determine differences between treatment means.

\section{RESULTS AND DISCUSSION}

\section{BARN AND CATTLE SUMMARY}

The barn and cattle management conditions affecting the three sampling periods are listed in table 2 . The large ranges of conditions on the various sampling days are indicative of the range of management practices among producers. There were instances of partially emptied pens for barn F (fall) and barn $\mathrm{H}$ (spring) and empty pens for barn $\mathrm{F}$ (fall) and barn $\mathrm{R}$ (all seasons). Barn F raises beef breeds of cattle; cattle typically come into the barn in the late fall and are marketed in early fall of the following year. At this time, the manure is removed from the deep-pit storage and land-applied. The fall sampling period preceded manure removal by one week. Barn $\mathrm{H}$ continuously stocked Holstein steers of various weights among the pens. Barn R finished Holsteins and beef breeds. Barn $\mathrm{H}$ and barn $\mathrm{R}$ typically remove manure in late fall; however, regional wet conditions in the fall delayed complete manure removal per the typical schedule. Barn $\mathrm{H}$ was able to remove some manure earlier in the fall season but also moved manure between pits to provide adequate storage until full removal was possible in later fall. Barn $\mathrm{R}$

Table 2. Barn and cattle management conditions at three deep-pit cattle barns during three sampling periods.

\begin{tabular}{|c|c|c|c|c|c|c|c|c|c|c|c|c|}
\hline \multirow{3}{*}{$\begin{array}{l}\text { Sampling Period } \\
\text { and Description }\end{array}$} & \multicolumn{4}{|c|}{ Barn F } & \multicolumn{4}{|c|}{ Barn $\mathrm{H}$} & \multicolumn{4}{|c|}{ Barn R } \\
\hline & \multicolumn{2}{|c|}{ West Pit } & \multicolumn{2}{|c|}{ East Pit } & \multicolumn{2}{|c|}{ East Pit } & \multicolumn{2}{|c|}{ West Pit } & \multicolumn{4}{|c|}{ Common Pit } \\
\hline & 1 & 2 & 3 & 4 & 2 & 13 & 6 & 9 & 1 & 2 & 3 & 4 \\
\hline \multicolumn{13}{|l|}{ Summer (July 2018) } \\
\hline Number of cattle per pen & 105 & 105 & 116 & 117 & 129 & 125 & 121 & 131 & 59 & 57 & 0 & 0 \\
\hline Type & \multicolumn{4}{|c|}{ Mixed beef breeds } & \multicolumn{4}{|c|}{ Holstein steers } & \multicolumn{2}{|c|}{ Holstein steers } & - & - \\
\hline Average cattle weight $(\mathrm{kg})$ & 562 & 562 & 553 & 553 & 472 & 508 & 544 & 431 & 463 & 463 & 0 & 0 \\
\hline Average manure depth (m) & 1.91 & 1.91 & 1.75 & 1.75 & 2.69 & 2.69 & 1.98 & 1.98 & 1.80 & 1.80 & 1.80 & 1.80 \\
\hline Feed delivery time & \multicolumn{4}{|c|}{$0700 \mathrm{~h}$ and $1630 \mathrm{~h}$} & \multicolumn{4}{|c|}{$0800 \mathrm{~h}$ and $1700 \mathrm{~h}$} & \multicolumn{4}{|c|}{$0600 \mathrm{~h}$} \\
\hline Dry matter feed intake $\left(\mathrm{kg} \mathrm{d}^{-1}\right)$ & 10.8 & 10.8 & 10.8 & 10.8 & 9.6 & 9.9 & 10.3 & 9.2 & 9.5 & 9.5 & 0.0 & 0.0 \\
\hline $\begin{array}{l}\text { Recent manure events or } \\
\text { other farm activities }\end{array}$ & \multicolumn{4}{|c|}{$\mathrm{n} / \mathrm{a}$} & \multicolumn{4}{|c|}{$\mathrm{n} / \mathrm{a}$} & \multicolumn{4}{|c|}{$\mathrm{n} / \mathrm{a}$} \\
\hline Curtain opening (m) & \multicolumn{4}{|c|}{5.3} & \multicolumn{4}{|c|}{2.8 north and 2.8 south } & \multicolumn{4}{|c|}{2.5} \\
\hline \multicolumn{13}{|l|}{ Fall (September 2018) } \\
\hline Number of cattle per pen & 37 & 34 & 0 & 0 & 126 & 121 & 120 & 130 & 58 & 57 & 0 & 0 \\
\hline Type & \multicolumn{2}{|c|}{ Mixed beef breeds } & - & - & \multicolumn{4}{|c|}{ Holstein steers } & \multicolumn{2}{|c|}{ Holstein steers } & - & - \\
\hline Average cattle weight $(\mathrm{kg})$ & 619 & 619 & 0 & 0 & 553 & 590 & 516 & 515 & 540 & 540 & 0 & 0 \\
\hline Average manure depth (m) & 0.51 & 0.51 & 0.15 & 0.15 & 3.05 & 3.02 & 2.9 & 2.9 & 2.06 & 2.06 & 2.06 & 2.06 \\
\hline Feed delivery time & \multicolumn{4}{|c|}{$0700 \mathrm{~h}$ and $1630 \mathrm{~h}$} & \multicolumn{4}{|c|}{$0800 \mathrm{~h}$ and $1700 \mathrm{~h}$} & & 060 & & \\
\hline Dry matter feed intake $\left(\mathrm{kg} \mathrm{d}^{-1}\right)$ & 9.03 & 9.03 & 0.00 & 0.00 & 9.21 & 9.75 & 9.46 & 8.96 & 9.5 & 9.5 & 0.00 & 0.00 \\
\hline $\begin{array}{l}\text { Recent manure events or } \\
\text { other farm activities }\end{array}$ & $\begin{array}{r}\text { Pumpe } \\
\text { pling; p } \\
\text { pad nor } \\
t\end{array}$ & $\begin{array}{l}\text { nanure } \\
\text { lucer pi } \\
\text { vest of } \\
\text { fic on } n\end{array}$ & $\begin{array}{l}\text { eek pr } \\
\text { ylage } \\
\text { vith ex } \\
\text { ide of }\end{array}$ & $\begin{array}{l}\text { to sam- } \\
\text { concrete } \\
\text { vehicle } \\
\end{array}$ & $\begin{array}{l}\text { Pumpe } \\
\text { to wes }\end{array}$ & $\begin{array}{l}0.3 \mathrm{~m} \\
\text { it one }\end{array}$ & $\begin{array}{l}\text { ft) fror } \\
\text { k prior } \\
\text { g }\end{array}$ & $\begin{array}{l}\text { east pit } \\
\text { o sam- }\end{array}$ & & $\boldsymbol{n}$ & & \\
\hline Curtain opening $(\mathrm{m})$ & & & & & & north & 2.8 so & & & 1 & & \\
\hline Spring (March-April 2019) & & & & & & & & & & & & \\
\hline Number of cattle per pen & 138 & 115 & 124 & 123 & 15 & 68 & 118 & 122 & 74 & 72 & 71 & \\
\hline Type & & Mixed & preeds & & & Holst & steers & & Beef & Holste & n steers & - \\
\hline Average cattle weight $(\mathrm{kg})$ & 408 & 386 & 299 & 590 & 635 & 626 & 635 & 612 & 440 & 340 & 340 & \\
\hline Average manure depth (m) & 1.82 & 1.79 & 1.96 & 1.89 & 2.31 & 2.36 & 2.44 & 2.44 & 2.74 & 2.74 & 2.74 & 2.74 \\
\hline Feed delivery time & & $0730 \mathrm{~h}$ & $600 \mathrm{~h}$ & & & $800 \mathrm{~h}$ & 1700 & & & 060 & & \\
\hline Dry matter feed intake $\left(\mathrm{kg} \mathrm{d}^{-1}\right)$ & 8.89 & 8.94 & 8.80 & 9.71 & 9.75 & 9.74 & 9.61 & 9.03 & 9.16 & 8.85 & 8.85 & \\
\hline $\begin{array}{l}\text { Recent manure events or } \\
\text { other farm activities }\end{array}$ & & rozen $n$ & surfa & & $\begin{array}{l}\text { Produc } \\
\text { nure ce } \\
\text { formu } \\
\text { that in }\end{array}$ & $\begin{array}{l}\text { notic } \\
\text { sisten } \\
\text { ion ch } \\
\text { uded } \\
\text { (we }\end{array}$ & $\begin{array}{l}\text { chang } \\
\text { ollowir } \\
\text { e in D } \\
\text { lified d } \\
\text { ke) }\end{array}$ & $\begin{array}{l}\text { in ma- } \\
\text { a feed } \\
\text { ember } \\
\text { tillers }\end{array}$ & & II & & \\
\hline Curtain opening (m) & & & & & 1.1 & north & $1.1 \mathrm{~m}$ & uth & & 1 & & \\
\hline
\end{tabular}


was not able to remove manure and access the fields for manure application until after the spring sampling period. Barns $\mathrm{F}$ and $\mathrm{H}$ fed twice daily, and barn $\mathrm{R}$ fed once daily.

\section{Feed Composition}

The nutrient compositions of feed samples (table 3) represent snapshots of the feed management in these barns and do not represent the feed consumed over the entire monitoring project. However, the nutrient compositions of the diets across barns and sampling periods are typical for cattle finishing diets in North America (Samuelson et al., 2016), with the exception of the diet fed to pen 3 of barn $F$ during the spring sampling period. That diet contained a greater concentration of neutral detergent fiber and less net energy for gain compared to the diets fed at other locations and sampling times, consistent with a typical receiving diet fed for a short period of time to lighter-weight (i.e., $299 \mathrm{~kg}$ ) cattle.

Feed composition affects manure quality (ASABE, 2014) and rumination, which influence gas production rates and air quality in the barn. Table 3 suggests that there was slightly higher crude protein in the barn $\mathrm{F}$ feed compared to barns $\mathrm{H}$ and R. Depending on actual feed intake, additional crude protein in the feed could translate to additional nitrogen in the manure (see the Manure Composition section). Dry matter intake is considered in estimating manure excretion (ASABE, 2014). We lacked feed intake and composition data between sampling periods; thus, no comparison was made to total manure production rates.

\section{Water Quality}

All of the water samples analyzed (table 4) met standards of acceptability for livestock consumption (NASEM, 2016). The average of the barn $\mathrm{F}$ water sulfate concentration was 115 and 22 times greater than that of barns $\mathrm{H}$ and $\mathrm{R}$, respectively. Assuming a $48 \mathrm{~L}_{\text {head }}{ }^{-1} \mathrm{~d}^{-1}$ water intake (NASEM, 2016), the cattle in barn F consumed approximately $5.7 \mathrm{~g}$ of elemental $\mathrm{S}$ per day, compared to 0.05 and $0.23 \mathrm{~g} \mathrm{~d}^{-1}$ for barns $\mathrm{H}$ and $\mathrm{R}$, respectively. Combined with the reported dry matter intake and dietary sulfur composition values, the cattle in barn $\mathrm{F}$ consumed $63 \%$ and $37 \%$ more elemental sulfur than the cattle in barns $\mathrm{H}$ and $\mathrm{R}$, respectively, which could explain some of the barn-to-barn variation in manure sulfur content and $\mathrm{H}_{2} \mathrm{~S}$ gas concentrations observed (discussed in later sections). The chloride concentration in barn $\mathrm{F}$ in fall was less than half of the summer measurement. The barn $\mathrm{H}$ chloride level also dropped by one-third between summer and fall. Chloride, and other water-based nutrient concentrations, may fluctuate with changes in water flow and evaporation differences between seasons. Nitrate- $\mathrm{N}$ levels were noticeably higher in barn $\mathrm{R}$ than in barns $\mathrm{F}$ and $\mathrm{H}$, but $\mathrm{N}$ intake via water was still less than $1 \%$ of the $\mathrm{N}$ intake via feed for barn R.

\section{Manure Composition}

Table 5 lists the surface and agitated manure compositions for the three barns. Agitated manure was assumed representative of the whole manure storage. Variation in composition between barns and seasons was expected because of feed composition (table 3), water quality (table 4), and other

Table 3. Feed composition (expressed as \% dry matter unless noted) by barn, pen, and season.

\begin{tabular}{|c|c|c|c|c|c|c|}
\hline Season & Component & \multicolumn{2}{|c|}{ Barn F } & \multicolumn{2}{|c|}{ Barn $\mathrm{H}$} & \multirow{2}{*}{$\begin{array}{c}\text { Barn R } \\
\text { All Pens }\end{array}$} \\
\hline \multirow{11}{*}{ Summer } & & Pens 1 and 2 & Pens 3 and 4 & Pens 2 and 13 & Pens 6 and 9 & \\
\hline & Dry matter (\% as-fed) & 61.5 & 60.2 & 72.8 & 70.5 & 68.4 \\
\hline & Crude protein & 12.9 & 13.5 & 11.7 & 10.8 & 11.1 \\
\hline & Neutral detergent fiber & 19.2 & 18.2 & 13.4 & 12.1 & 18.5 \\
\hline & Fat & 4.38 & 4.38 & 3.56 & 2.54 & 3.25 \\
\hline & $\operatorname{NEg}\left(\mathrm{MJ} \mathrm{kg}^{-1}\right)$ & 6.55 & 6.83 & 6.64 & 6.55 & 6.55 \\
\hline & Phosphorus & 0.44 & 0.41 & 0.41 & 0.36 & 0.36 \\
\hline & Calcium & 0.85 & 0.56 & 0.77 & 0.75 & 0.37 \\
\hline & Potassium & 0.61 & 0.56 & 0.71 & 0.64 & 0.67 \\
\hline & Sulfur & 0.24 & 0.22 & 0.19 & 0.15 & 0.2 \\
\hline & Ash & 4.66 & 4.11 & 5.09 & 5.02 & 3.95 \\
\hline \multirow{11}{*}{ Fall } & & & & \multicolumn{2}{|c|}{ All Pens } & All Pens \\
\hline & Dry matter (\% as-fed) & - & - & \multicolumn{2}{|c|}{69.2} & 53.9 \\
\hline & Crude protein & - & - & \multicolumn{2}{|c|}{11.9} & 13.6 \\
\hline & Neutral detergent fiber & - & - & \multicolumn{2}{|c|}{15.7} & 19.5 \\
\hline & Fat & - & - & \multicolumn{2}{|c|}{2.85} & 3.05 \\
\hline & $\operatorname{NEg}\left(\mathrm{MJ} \mathrm{kg}^{-1}\right)$ & - & - & \multicolumn{2}{|c|}{6.27} & 6.00 \\
\hline & Phosphorus & - & - & \multicolumn{2}{|c|}{0.43} & 0.51 \\
\hline & Calcium & - & - & \multicolumn{2}{|c|}{0.82} & 0.68 \\
\hline & Potassium & - & - & \multicolumn{2}{|c|}{0.77} & 0.82 \\
\hline & Sulfur & - & - & \multicolumn{2}{|c|}{0.17} & 0.25 \\
\hline & Ash & - & - & \multicolumn{2}{|c|}{5.52} & 5.86 \\
\hline \multirow{11}{*}{ Spring } & & Pens 1,2 , and 4 & Pen 3 & \multicolumn{2}{|c|}{ All Pens } & All Pens \\
\hline & Dry matter (\% as-fed) & 69.6 & 53.5 & \multicolumn{2}{|c|}{62.6} & 64.1 \\
\hline & Crude protein & 11.7 & 10.6 & \multicolumn{2}{|c|}{9.7} & 9.8 \\
\hline & Neutral detergent fiber & 18.4 & 26.6 & \multicolumn{2}{|c|}{13.9} & 17.5 \\
\hline & Fat & 4.65 & 3.47 & \multicolumn{2}{|c|}{4.21} & 4.85 \\
\hline & $\operatorname{NEg}\left(\mathrm{MJ} \mathrm{kg}^{-1}\right)$ & 6.36 & 5.35 & \multicolumn{2}{|c|}{6.55} & 6.55 \\
\hline & Phosphorus & 0.48 & 0.36 & \multicolumn{2}{|c|}{0.4} & 0.47 \\
\hline & Calcium & 1.14 & 0.99 & \multicolumn{2}{|c|}{0.85} & 0.57 \\
\hline & Potassium & 0.64 & 0.67 & \multicolumn{2}{|c|}{0.65} & 0.74 \\
\hline & Sulfur & 0.22 & 0.21 & \multicolumn{2}{|c|}{0.18} & 0.17 \\
\hline & Ash & 6.66 & 8.38 & \multicolumn{2}{|c|}{6.07} & 5.48 \\
\hline
\end{tabular}


Table 4. Water quality by barn and season. ${ }^{[\mathrm{a}]}$

\begin{tabular}{|c|c|c|c|c|c|c|c|c|}
\hline \multirow{2}{*}{$\begin{array}{l}\text { Component } \\
\text { (ppm) }\end{array}$} & \multicolumn{2}{|c|}{ Barn F } & \multicolumn{3}{|c|}{ Barn H } & \multicolumn{3}{|c|}{ Barn R } \\
\hline & Summer & Fall & Summer & Fall & Spring & Summer & Fall & Spring \\
\hline Fluoride & 0.06 & 0.06 & 0.06 & 0.09 & 0.07 & 0.03 & 0.05 & 0.04 \\
\hline Chloride & 1.97 & 0.74 & 0.27 & 0.18 & 0.16 & 37.6 & 39.3 & 31.1 \\
\hline Bromide & 0.06 & 0.05 & 0.03 & n.d. & 0.03 & 0.06 & 0.07 & 0.06 \\
\hline Nitrate-N & n.d. & n.d. & 0.02 & 0.02 & 0.02 & 9.32 & 9.73 & 7.92 \\
\hline Sulfate & 322.1 & 393.3 & 3.0 & 3.6 & 2.7 & 17.8 & 18.3 & 13.5 \\
\hline Phosphate & n.d. & n.d. & n.d. & n.d. & n.d. & n.d. & n.d. & 0.04 \\
\hline
\end{tabular}

Table 5. Composition of surface and agitated (mixed) manure by manure pit and pen for three deep-pit beef cattle finishing barns.

\begin{tabular}{|c|c|c|c|c|c|c|c|c|c|c|c|c|c|}
\hline \multirow{3}{*}{$\begin{array}{l}\text { Characteristic and } \\
\text { Sampling Period }\end{array}$} & \multirow[b]{3}{*}{ Type } & \multicolumn{4}{|c|}{ Barn F } & \multicolumn{4}{|c|}{ Barn $\mathrm{H}$} & \multirow{2}{*}{\multicolumn{4}{|c|}{$\begin{array}{c}\text { Barn R } \\
\text { Common Pens }\end{array}$}} \\
\hline & & \multicolumn{2}{|c|}{ West Pens } & \multicolumn{2}{|c|}{ East Pens } & \multicolumn{2}{|c|}{ East Pens } & \multicolumn{2}{|c|}{ West Pens } & & & & \\
\hline & & 1 & 2 & 3 & 4 & 2 & 13 & 6 & 9 & 1 & 2 & 3 & 4 \\
\hline \multicolumn{14}{|l|}{ Dry matter (\% w.b.) } \\
\hline July 2018 & Surface & 17.4 & 17.0 & 16.4 & 15.9 & 8.9 & 10.5 & 11.7 & 10.8 & 15.4 & 14.1 & 12.4 & 7.2 \\
\hline Sept. 2018 & Surface & - & - & - & - & 17.0 & 19.4 & 9.1 & 9.3 & 14.6 & 12.2 & 7.7 & 7.0 \\
\hline Mar.-Apr. 2019 & Surface & 10.2 & 23 & 18.8 & 20 & 12.9 & 15.0 & 12.5 & 13.6 & 6.2 & 7.7 & 3.2 & 3.7 \\
\hline Fall & Agitated & - & - & 13.4 & - & 12.7 & - & 10.4 & - & - & - & - & - \\
\hline Spring & Agitated & - & - & - & - & 11.4 & - & 12.1 & - & 13.1 & - & - & - \\
\hline \multicolumn{14}{|l|}{ Total nitrogen $\left(\mathrm{g} \mathrm{L}^{-1}\right)$} \\
\hline July 2018 & Surface & 8.15 & 7.80 & 7.68 & 8.56 & 5.94 & 6.59 & 5.95 & 6.03 & 7.22 & 7.17 & 6.43 & 5.17 \\
\hline Sept. 2018 & Surface & - & - & & & 7.80 & 6.96 & 5.53 & 5.10 & 7.57 & 6.93 & 4.83 & 4.61 \\
\hline Mar.-Apr. 2019 & Surface & 7.73 & 10.55 & 8.99 & 8.77 & 5.53 & 6.13 & 5.61 & 5.69 & 5.50 & 5.30 & 2.78 & 2.47 \\
\hline Fall & Agitated & - & - & 6.81 & - & 6.20 & - & 5.18 & - & - & - & - & - \\
\hline Spring & Agitated & - & - & - & - & 6.70 & - & 4.58 & - & 4.83 & - & - & - \\
\hline \multicolumn{14}{|c|}{ Ammonium nitrogen $\left(\mathrm{g} \mathrm{L}^{-1}\right)$} \\
\hline July 2018 & Surface & 3.99 & 3.73 & 3.76 & 4.60 & 3.64 & 3.77 & 3.27 & 3.55 & 2.92 & 3.09 & 3.09 & 3.52 \\
\hline Sept. 2018 & Surface & - & - & & & 3.73 & 3.87 & 3.08 & 2.97 & 3.35 & 3.16 & 2.76 & 3.07 \\
\hline Mar.-Apr. 2019 & Surface & 4.98 & 4.81 & 4.50 & 3.99 & 2.44 & 2.69 & 2.99 & 2.71 & 4.14 & 3.45 & 2.01 & 1.66 \\
\hline Fall & Agitated & - & - & 4.41 & - & 3.80 & - & 3.52 & - & - & - & - & - \\
\hline Spring & Agitated & - & - & - & - & 4.09 & - & 2.77 & - & 2.61 & - & - & - \\
\hline \multicolumn{14}{|l|}{ Phosphorus as $\mathrm{P}_{2} \mathrm{O}_{5}\left(\mathrm{~g} \mathrm{~L}^{-1}\right)$} \\
\hline July 2018 & Surface & 4.89 & 4.07 & 4.31 & 3.77 & 2.80 & 3.91 & 3.79 & 3.45 & 4.39 & 3.44 & 2.94 & 2.19 \\
\hline Sept. 2018 & Surface & - & - & & & 4.66 & 6.82 & 3.30 & 2.91 & 4.47 & 4.04 & 2.67 & 2.46 \\
\hline Mar.-Apr. 2019 & Surface & 2.79 & 5.99 & 5.28 & 5.34 & 4.18 & 5.10 & 4.37 & 4.63 & 3.10 & 3.73 & 1.60 & 1.22 \\
\hline Fall & Agitated & - & - & 2.81 & - & 4.17 & - & 3.44 & - & - & - & - & - \\
\hline Spring & Agitated & - & - & - & - & 3.28 & - & 3.48 & - & 3.80 & - & - & - \\
\hline \multicolumn{14}{|c|}{ Total potassium as $\mathrm{K}_{2} \mathrm{O}\left(\mathrm{g} \mathrm{L}^{-1}\right)$} \\
\hline July 2018 & Surface & 5.22 & 4.45 & 4.53 & 4.28 & 6.23 & 5.15 & 4.77 & 4.86 & 4.99 & 4.77 & 3.92 & 3.00 \\
\hline Sept. 2018 & Surface & - & - & - & - & 5.67 & 8.14 & 4.32 & 3.60 & 5.31 & 4.89 & 4.19 & 4.81 \\
\hline Mar.-Apr. 2019 & Surface & 4.48 & 5.45 & 5.13 & 5.00 & 3.92 & 4.83 & 4.75 & 4.39 & 7.60 & 7.72 & 3.97 & 3.16 \\
\hline Fall & Agitated & - & - & 3.70 & - & 3.96 & - & 3.66 & - & - & - & - & - \\
\hline Spring & Agitated & - & - & - & - & 4.13 & - & 3.89 & - & 4.47 & - & - & - \\
\hline \multicolumn{14}{|l|}{$\overline{\text { Sulfur, }\left(\mathrm{g} \mathrm{L}^{-1}\right)}$} \\
\hline July 2018 & Surface & 2.48 & 2.25 & 2.30 & 2.20 & 1.00 & 1.10 & 0.97 & 1.10 & 2.44 & 1.21 & 0.94 & 0.57 \\
\hline Sept. 2018 & Surface & - & - & - & - & 1.46 & 1.72 & 0.92 & 0.72 & 1.32 & 1.17 & 0.73 & 0.72 \\
\hline Mar.-Apr. 2019 & Surface & 1.58 & 2.22 & 2.06 & 2.01 & 0.81 & 0.94 & 0.91 & 0.92 & 1.20 & 1.30 & 0.63 & 0.54 \\
\hline Fall & Agitated & - & - & 1.38 & - & 0.28 & - & 0.23 & - & - & - & - & - \\
\hline Spring & Agitated & - & - & - & - & 0.69 & - & 0.66 & - & 0.86 & - & - & - \\
\hline \multicolumn{14}{|l|}{ Ash (\% of dry matter) } \\
\hline July 2018 & Surface & 15.81 & 16.53 & 16.18 & 18.34 & 22.14 & 21.3 & 18.55 & 19.56 & 14.07 & 14.79 & 17.08 & 26.16 \\
\hline Sept. 2018 & Surface & - & - & - & - & 16.63 & 19.03 & 19.27 & 19.71 & 16.64 & 18.02 & 21.59 & 26.47 \\
\hline Mar.-Apr. 2019 & Surface & 21.69 & 15.15 & 18.2 & 17.43 & 18.38 & 18.52 & 19.01 & 18.17 & 33.75 & 27.76 & 36.72 & 32.5 \\
\hline Fall & Agitated & - & - & - & - & 20.9 & - & 20.54 & - & - & - & - & - \\
\hline Spring & Agitated & - & - & - & - & 19.82 & - & 19.14 & - & 18.04 & - & - & - \\
\hline
\end{tabular}

management practices such as water additions (table 1), in addition to seasonal temperatures. Water addition can dilute nutrients in manure; thus, concentrations do not always indicate differences in nutrient excretion by cattle between barns. However, the manure composition influences gas production and air quality. MWPS (2004) suggests planning for finishing cattle liquid pit manure with 3.5 and $1.0 \mathrm{~g} \mathrm{~L}^{-1}$ total $\mathrm{N}$ and $\mathrm{NH}_{4}-\mathrm{N}$, respectively, as well as $2.2 \mathrm{~g} \mathrm{~L}^{-1} \mathrm{P}_{2} \mathrm{O}_{5}$ and 3.1 $\mathrm{g} \mathrm{L}^{-1} \mathrm{~K}_{2} \mathrm{O}$, but does not indicate the storage system type with this estimate. In general, the agitated manure samples collected at barns $\mathrm{F}, \mathrm{H}$, and $\mathrm{R}$ indicated that the manure total $\mathrm{N}$ was greater than published estimates (from 4.5 to $6.7 \mathrm{~g} \mathrm{~L}^{-1}$ ), and ammonium-N was $50 \%$ to $65 \%$ of the total N. Phosphorus can be up to twice the MWPS (2004) values (fig. 4). These measurements emphasize the need for timely manure sampling to guide manure application decisions.

The surface manure samples showed differences in manure composition for pens that shared a common pit. Day to day, the only agitation of manure was that caused by urine or feces additions on the manure surface. Therefore, the amount of mixing was low, but settling and diffusion within the manure can move nutrients from where they are deposited. A variation in crust and/or solids may explain some of the variation between pens for nutrients associated with the 


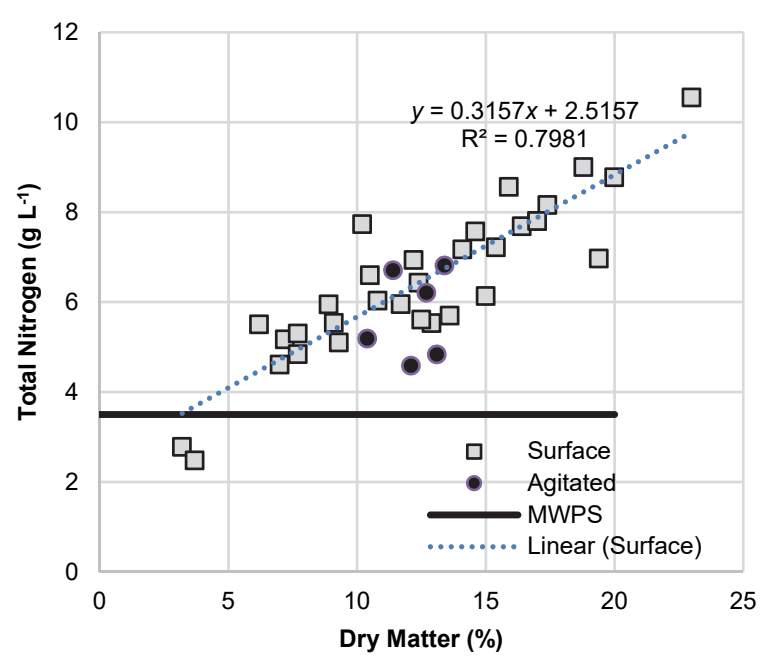

(a)

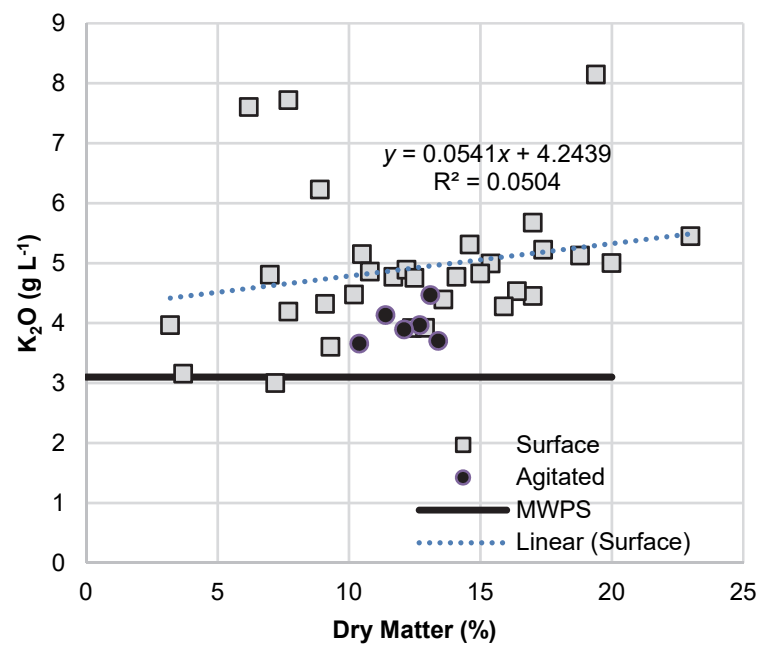

(c)

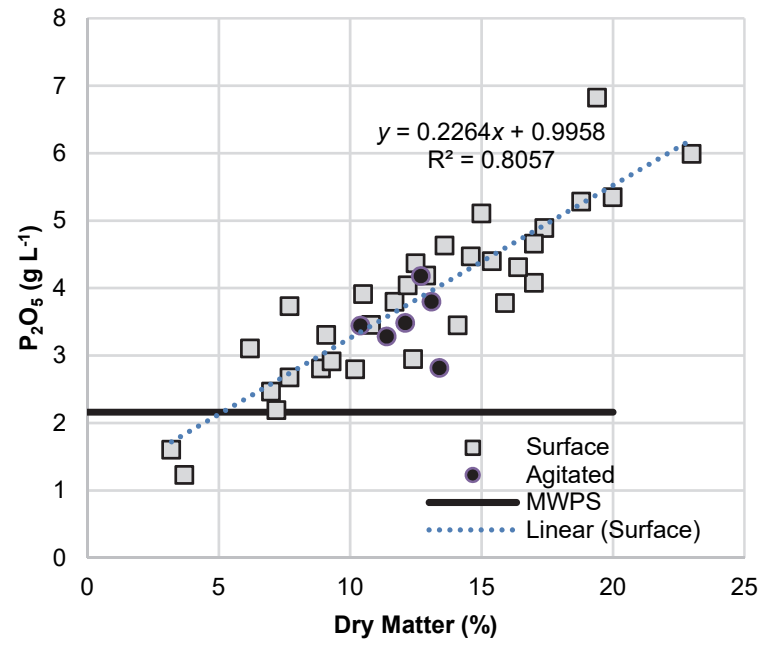

(b)

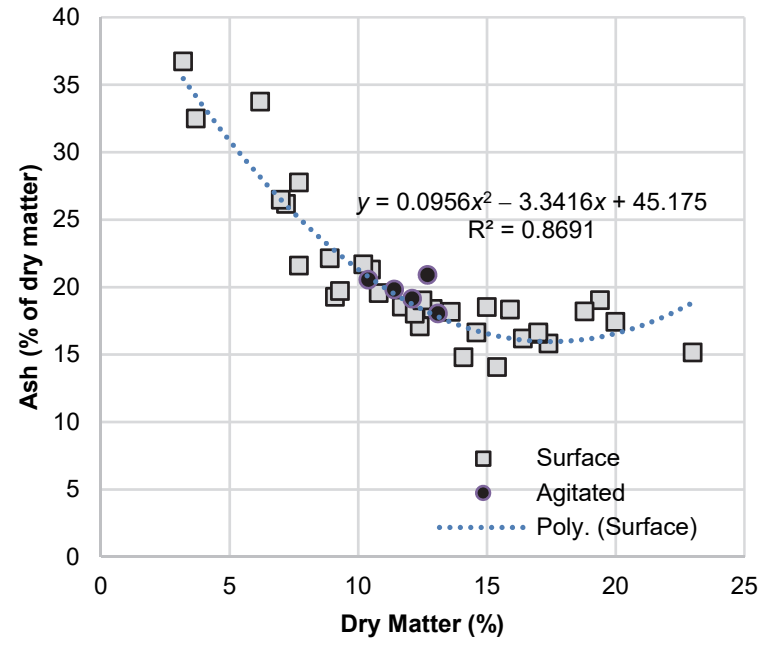

(d)

Figure 4. Manure characteristics for surface and agitated samples for deep-pit manure storage in three cattle barns, relative to dry matter (solids) content. The MWPS line provides a reference literature value (MWPS, 2004).

solid manure material (fig. 4). Phosphorus is associated with fecal (versus urinary) output, while potassium is considered greater in urine compared to fecal output (MWPS, 2004). Total nitrogen is assumed evenly distributed between urine and feces (MWPS, 2004), with organic nitrogen in fecal material and ammonium in urine. There was noticeably more crust on the surface of barn $\mathrm{F}$ manure relative to the other two barns. Pen 4 in barn R remained empty of animals over the entire project, and pen 3 was empty during the fall period. The manure surface under pens 3 and 4 was noticeably lower in solids; this was attributed to settling of manure solids. For all barns and seasons, there was a strong relationship between dry matter and total nitrogen $\left(\mathrm{R}^{2}=0.80\right)$, phosphate $\left(\mathrm{R}^{2}=0.81\right)$, and ash $\left(\mathrm{R}^{2}=0.87\right.$ for a second-order polynomial relationship). Higher ash, or inorganic dry matter content, may be related to a lack of fresh manure additions under pens with no cattle.

Manure sulfur was greater at barn F compared to the other barns, which may be attributed to the water quality (table 4) and slightly higher sulfur content of the feed. At the surface, total nitrogen and total ammoniacal-N were also greater in barn $\mathrm{F}$ manure in most instances. However, the total $\mathrm{N}$ content of barn $\mathrm{F}$ agitated manure in the fall was only $0.1 \mathrm{~g} \mathrm{~L}^{-1}$ higher than the east pit of barn $\mathrm{H}$ in the spring. The presence of solids or crust at the manure surface may explain some of these differences between barn $\mathrm{F}$ and the other barns for surface versus agitated manure nitrogen content. A large proportion of the nitrogen may have been bound in the dry matter at the surface (fig. 4). Crust is often considered a barrier for gas release. In this case, it may have also served as a sink for nitrogen close to the surface, with opportunity for release.

Without convenient openings in the floor to draw samples, most deep-pit manure systems rely on infrequent samples collected during manure agitation and removal. Sample analysis often occurs after application, and the sample analysis results inform the next year's nutrient management plans. Surface samples alone appear an inadequate substitute for agitated manure sample analyses, unless the dry matter or solids are more evenly distributed throughout the storage depth than they were in barn $\mathrm{F}$ and barn $\mathrm{R}$. 


\section{ENVIRONMENTAL CONDITIONS \\ Temperature and Humidity}

At the regional weather stations, the average air temperatures for the measurement days were $4.4^{\circ} \mathrm{C}$ to $27.8^{\circ} \mathrm{C}$ for barn $\mathrm{F}, 7.2^{\circ} \mathrm{C}$ to $23.9^{\circ} \mathrm{C}$ for barn $\mathrm{H}$, and $10.8^{\circ} \mathrm{C}$ to $18.2^{\circ} \mathrm{C}$ for barn $\mathrm{R}$ (table 6). The average air temperature for the fall monitoring period was more than $10^{\circ} \mathrm{C}$ higher at barn $\mathrm{F}$ than at barns $\mathrm{F}$ and $\mathrm{R}$. While these barns and monitoring periods were separated geographically and temporally (by at least a week), large temperature swings are frequent during the fall and spring transition seasons. Below-freezing conditions are part of the annual temperature cycle for this region, but below-freezing weather was not conducive to on-site gas analyzer use. Future research to expand the range of conditions for measurements is beneficial, particularly to investigate the conditions during freezing conditions. This research did not capture the lag in response to changes in weather.

Temperatures under the roof, at the floor, and at the manure surface were generally $6^{\circ} \mathrm{C}, 5^{\circ} \mathrm{C}$, and $2^{\circ} \mathrm{C}$ higher than the average regional air temperatures for the same period, respectively (fig. 5a). Cattle position (lying versus standing) and urination/defecation behaviors by the cattle influence floor surface temperatures, so an average of multiple measurements helped to compensate for the variation. Recent urinations or defecations also affected manure surface temperatures. While the surface measurement was above freezing in spring for barn $\mathrm{F}$, the manure surface was frozen (the manure sampler was unable to penetrate the surface) under all pens. Similarly, in spring for barn R, there was a thin layer of ice for parts of pen 4 (with no cattle) in the center to north side of the pen, which was shaded from sunlight.

Air temperatures at the wall, nose, floor, and manure levels did not differ significantly from the regional ambient air temperature for the same period (fig. 5b), suggesting that the regional weather station was a representative dataset for these farms. This may not be the case for all farms, as microclimates can develop based on topography and vegetation. Within each barn, air temperatures corresponding to gas sampling positions were significantly different by location, and the difference between locations changed with season (table 7). During summer (hot weather), the air temperature above the manure was significantly cooler than at other locations in barns F and H. During fall (mild weather), there were fewer significant differences between locations. In the spring (cool weather), the coolest air temperatures were either above the manure or at the inlet wall opening. Dewpoint temperatures varied similarly (table 7). Manure and floor surfaces can be wet and promote evaporative cooling of the surrounding air. The floor and manure surfaces were also partly sheltered from airflow through the barn, which may have limited mixing, and they were also under shade of the barn roof. In hot conditions, a decrease in temperature in addition to reduced solar radiation is a benefit to cattle. This dataset does not cover extreme cold conditions. Partial or complete closure of wall openings, thus altering airflow, is a normal operating procedure for most facilities of this type during extreme winter conditions, and this may influence air temperature distributions for freezing weather.

Table 6. Average environmental conditions for the three barns during the summer, fall, and spring sampling periods.

\begin{tabular}{|c|c|c|c|c|c|c|c|c|c|}
\hline \multirow[b]{2}{*}{ Description } & \multicolumn{3}{|c|}{ Barn F } & \multicolumn{3}{|c|}{ Barn H } & \multicolumn{3}{|c|}{ Barn R } \\
\hline & Summer & Fall & Spring & Summer & Fall & Spring & Summer & Fall & Spring \\
\hline \multicolumn{10}{|l|}{ Regional weather conditions } \\
\hline Air temperature $\left({ }^{\circ} \mathrm{C}\right)$ & 27.8 & 22.1 & 4.4 & 23.9 & 8.7 & 7.2 & 18.2 & 11.4 & 10.8 \\
\hline Relative humidity (\%) & 60.2 & 85.4 & 69.8 & 59.1 & 58.5 & 69.1 & 67.9 & 73.8 & 76.7 \\
\hline Wind speed $\left(\mathrm{m} \mathrm{s}^{-1}\right)$ & 1.1 & 0.8 & 9.2 & 4.3 & 5.0 & 4.9 & 5.9 & 8.9 & 2.0 \\
\hline Wind direction with respect to north (deg) & 303 & 278 & 348 & 302 & 325 & 183 & 319 & 317 & 250 \\
\hline N-S wind component speed $\left(\mathrm{m} \mathrm{s}^{-1}\right)$ & 1.0 & 0.8 & 1.9 & 3.7 & 2.9 & -0.3 & 3.9 & 6.0 & -1.9 \\
\hline E-W wind component speed $\left(\mathrm{m} \mathrm{s}^{-1}\right)$ & -0.6 & -0.1 & -9.0 & -2.2 & -4.1 & -4.9 & -4.5 & -6.5 & -0.7 \\
\hline \multicolumn{10}{|l|}{ Surface temperatures $\left({ }^{\circ} \mathrm{C}\right)$} \\
\hline Under roof & 31.7 & 23.6 & 9.0 & 28.8 & 15.2 & 14.9 & 22.2 & 14.7 & 12.1 \\
\hline Floor level & 27.1 & 22.4 & 8.3 & 25.0 & 15.3 & 13.2 & 20.9 & 15.0 & 11.1 \\
\hline Manure level & 25.3 & 20.4 & 4.4 & 23.1 & 13.7 & 8.6 & 19.8 & 15.2 & 6.3 \\
\hline \multicolumn{10}{|l|}{ Air temperature $\left({ }^{\circ} \mathrm{C}\right)$} \\
\hline North wall & 27.1 & 21.8 & 3.6 & 25.1 & 10.0 & 5.3 & 18.9 & 12.0 & 8.9 \\
\hline South wall & 27.6 & 21.5 & 4.4 & 25.1 & 11.9 & 6.5 & 18.2 & 11.9 & 7.7 \\
\hline Nose level & 27.8 & 21.8 & 4.5 & 24.8 & 11.7 & 8.5 & 18.6 & 12.0 & 8.6 \\
\hline Floor level & 27.5 & 21.8 & 4.3 & 24.6 & 11.6 & 8.1 & 18.6 & 12.2 & 8.7 \\
\hline Manure level & 27.0 & 21.0 & 3.4 & 22.5 & 10.4 & 7.2 & 19.0 & 11.9 & 7.2 \\
\hline \multicolumn{10}{|l|}{ Dewpoint temperature $\left({ }^{\circ} \mathrm{C}\right)$} \\
\hline North wall & 17.4 & 17.6 & 3.0 & 15.7 & 2.6 & 2.8 & 13.4 & 7.8 & 6.6 \\
\hline South wall & 18.1 & 17.5 & 3.5 & 16.9 & 3.1 & 4.2 & 13.7 & 8.1 & 6.5 \\
\hline Nose level & 18.5 & 17.4 & 3.6 & 16.1 & 4.0 & 5.7 & 13.5 & 8.0 & 6.5 \\
\hline Floor level & 19.0 & 17.5 & 3.8 & 16.6 & 5.1 & 6.0 & 13.6 & 8.3 & 7.0 \\
\hline Manure level & 20.5 & 17.7 & 4.4 & 18.3 & 4.8 & 6.1 & 14.6 & 9.0 & 6.7 \\
\hline \multicolumn{10}{|l|}{ Air movement through wall opening } \\
\hline Speed $\left(\mathrm{m} \mathrm{s}^{-1}\right)$ & - & 2.1 & 5.0 & - & 2.3 & 3.7 & - & 4.7 & 1.0 \\
\hline Direction with respect to north (deg) & - & 240 & 315 & - & 334 & 195 & - & 324 & 258 \\
\hline N-S component speed $\left(\mathrm{m} \mathrm{s}^{-1}\right)$ & - & 1.2 & 3.3 & - & 0.5 & -0.9 & - & 2.6 & -0.9 \\
\hline E-W component speed $\left(\mathrm{m} \mathrm{s}^{-1}\right)$ & - & 0.7 & -3.3 & - & -1.0 & -3.6 & - & -3.6 & -0.2 \\
\hline \multicolumn{10}{|l|}{ Air movement within pens ( $1.6 \mathrm{~m}$ above floor level) } \\
\hline Speed $\left(\mathrm{m} \mathrm{s}^{-1}\right)$ & 1.9 & 2.3 & 3.7 & 2.3 & 2.6 & 0.9 & 1.9 & 3.3 & 1.2 \\
\hline Absolute direction with respect to $\mathrm{N}$ and $\mathrm{E}$ (deg) & 60 & 56 & 39 & 44 & 33 & 10 & 50 & 46 & 54 \\
\hline Absolute N-S component speed $\left(\mathrm{m} \mathrm{s}^{-1}\right)$ & 1.6 & 1.9 & 2.3 & 1.6 & 1.4 & 0.2 & 1.5 & 2.3 & 0.9 \\
\hline Absolute E-W component speed $\left(\mathrm{m} \mathrm{s}^{-1}\right)$ & 0.9 & 1.3 & 2.9 & 1.7 & 2.2 & 0.8 & 1.2 & 2.3 & 0.7 \\
\hline
\end{tabular}




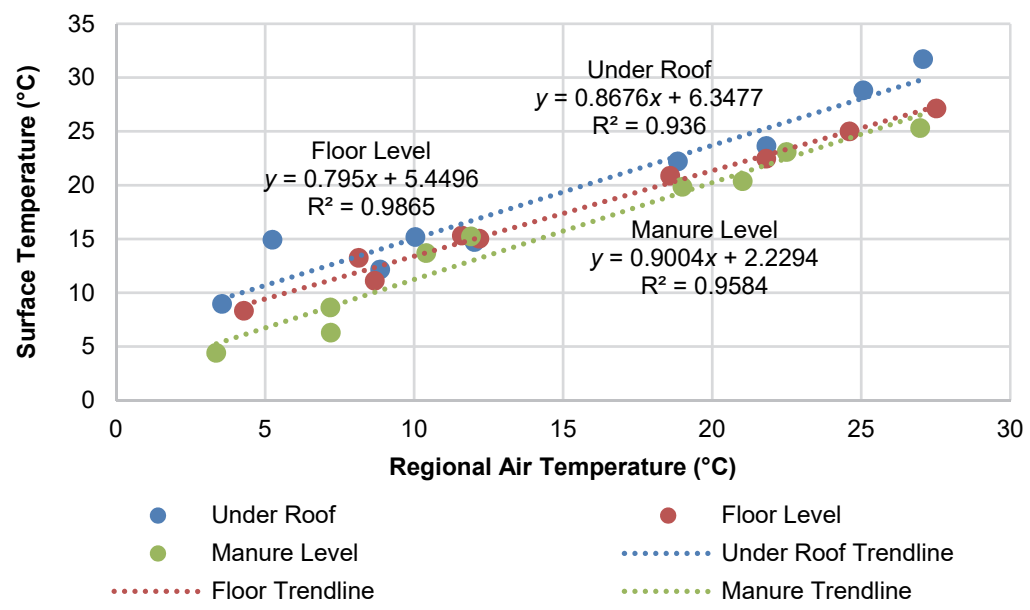

(a)

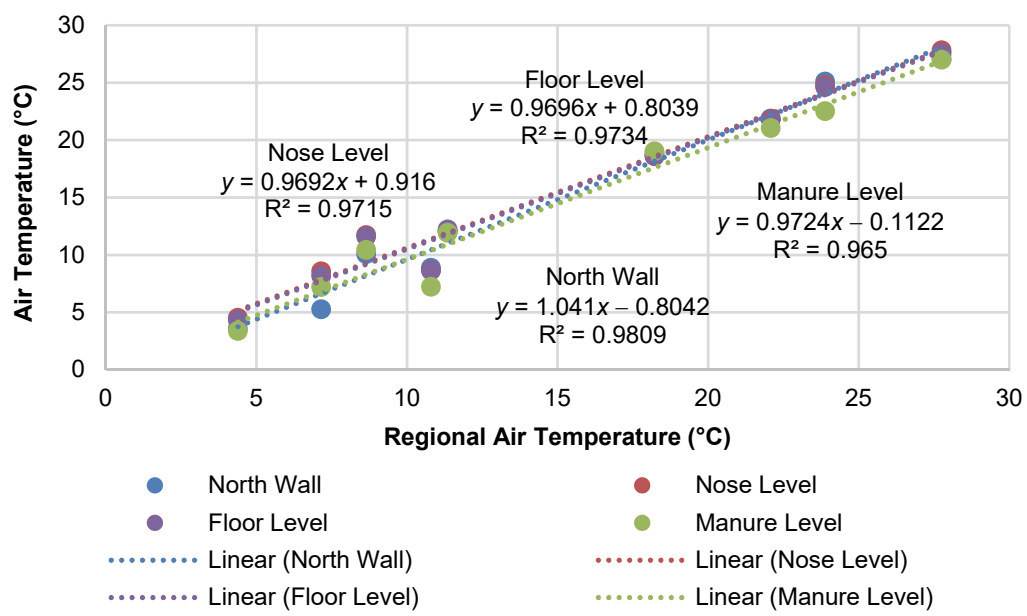

(b)

Figure 5. Comparison of (a) surface temperatures and (b) air (dry-bulb) temperatures with respect to regional conditions for the corresponding time at three deep-pit beef cattle finishing barns.

Table 7. Probability (p-values) for significant effects of factors for dry-bulb and dewpoint temperatures for the three barns.

\begin{tabular}{|c|c|c|c|c|c|c|}
\hline \multirow{2}{*}{$\begin{array}{c}\text { Treatment } \\
\text { Effects }\end{array}$} & \multicolumn{3}{|c|}{ Dry-Bulb Temperature } & \multicolumn{3}{|c|}{ Dewpoint Temperature } \\
\hline & Barn F & Barn $\mathrm{H}$ & Barn R & Barn F & Barn $\mathrm{H}$ & Barn R \\
\hline Pen & $<0.0001$ & 0.1567 & 0.0419 & 0.001 & 0.0009 & 0.0375 \\
\hline Location & $<0.0001$ & $<0.0001$ & $<0.0001$ & $<0.0001$ & $<0.0001$ & $<0.0001$ \\
\hline Pen $\times$ Location & 0.7384 & 0.669 & 0.6978 & 0.0018 & 0.9947 & 0.3652 \\
\hline Season & $<0.0001$ & $<0.0001$ & $<0.0001$ & $<0.0001$ & $<0.0001$ & $<0.0001$ \\
\hline Pen $\times$ Season & $<0.0001$ & 0.0005 & $<0.0001$ & 0.013 & 0.085 & 0.0034 \\
\hline Location $\times$ Season & $<0.0001$ & $<0.0001$ & $<0.0001$ & $<0.0001$ & 0.0003 & $<0.0001$ \\
\hline
\end{tabular}

\section{Air Movement}

Northwest winds were common for all monitoring periods except the barn $\mathrm{H}$ and barn $\mathrm{R}$ spring monitoring periods. The east-west orientation of the barns was designed for north-south winds to promote airflow and mixing (Jones et al., 2013). Prevailing winds for the weather stations near the monitoring sites are from the south for July and September and from the north for March and April (Weather Spark, 2019).

Figure 6a compares the measured air speed through the barns and at animal level to wind speed recorded at the local weather station. There was a consistent relationship between regional air speed and the air speed through the opening, evidenced by an $\mathrm{R}^{2}$ of 0.8178 for the nine data. The air speed through the opening was approximately $40 \%$ of the regional air speed. The anemometer placement in the north or south wall opening varied according to the curtain position, from 1 to $2 \mathrm{~m}$ above ground level. Meteorological stations typically measure wind speed and direction at $10 \mathrm{~m}$ above ground level, and the wind profile power law estimates that the wind speed at any height relative to a reference measurement is proportional to the ratio of corresponding heights to the power of 1/7 (Peterson and Hennessey, 1978). Accordingly, wind speed measurements at approximately $1.5 \mathrm{~m}$ above ground level should be approximately $40 \%$ of the air speed measured at $10 \mathrm{~m}$. The curtain openings at each site changed with the seasons to limit cold air drafts in cooler weather (tables 1 and 2). While there are constriction effects, the opening area likely does more to influence the volume of airflow through the barn versus the air speed through the 


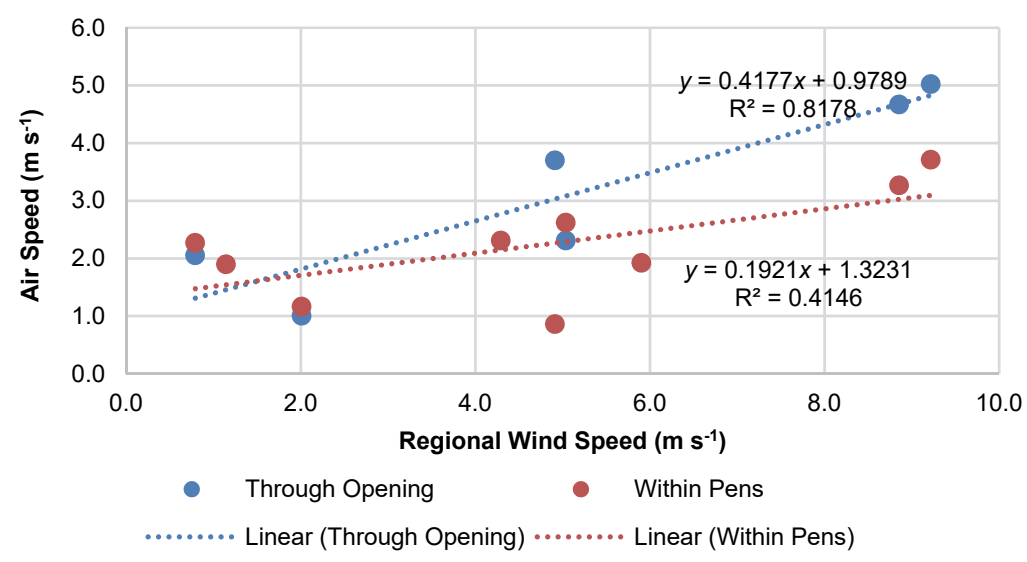

(a)

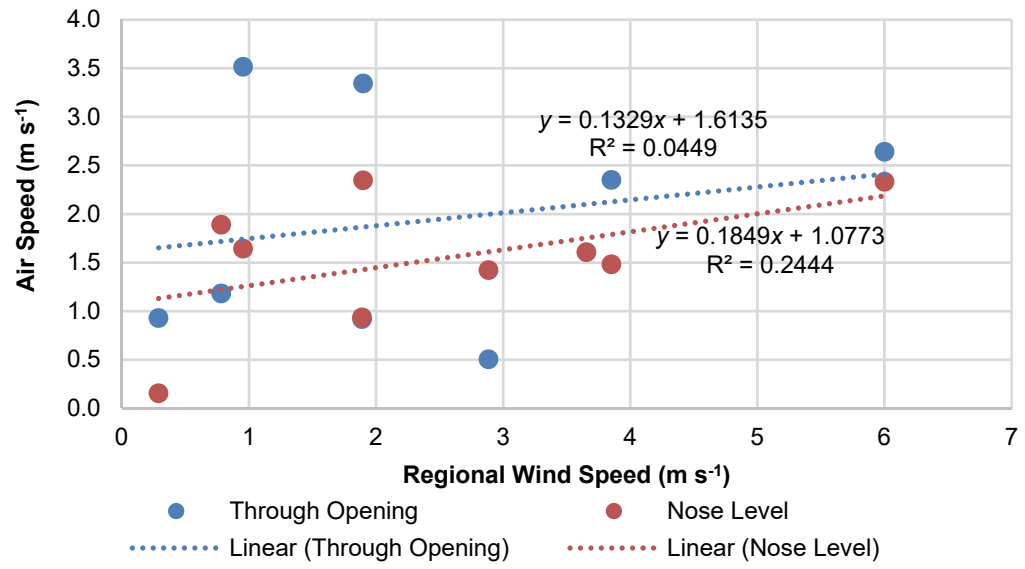

(b)

Figure 6. Comparison of (a) air speed and (b) N-S air speed component with respect to regional conditions for the corresponding time at three deep-pit beef cattle finishing barns.

opening. At animal level, the airflow patterns were less consistent with respect to regional wind speed $\left(\mathrm{R}^{2}=0.4146\right)$. During data collection, the project personnel observed that proximity to endwalls, curtain opening heights, and wind gusts influenced their personal comfort and induced measurement variation even within a common pen. The line of regression (fig. 6a) suggests that there was a relatively constant air speed at animal level of 1 to $3 \mathrm{~m} \mathrm{~s}^{-1}$, even if the wind dropped to near zero. The comparison of absolute air speed in the north-south plane was not as strong for the opening or at animal level (fig. 6b). Airflow estimates based on wind speed in the plane perpendicular to the opening (Cortus et al., 2015) are better served by on-site measurements than reliance on weather station data. The influences of roof type on air patterns were not investigated in this study.

\section{Gas ConCentrations}

Table 8 summarizes the significant factors and interactions for gas concentrations in the three barns. The significance of the pen factor was variable between barns for $\mathrm{NH}_{3}$ and combined sulfur but significant for $\mathrm{CO}_{2}$ in all barns $(\mathrm{p}<$ $0.01)$. Location and season were significant for all barns and gases $(p<0.05)$. The interaction of location and season was significant $(p<0.01)$ for barns $F$ and $H$ for all gases. The interaction of pen and season was significant for each barn with at least one of the three gases. Figures 7 and 8 show the average gas concentrations for the three barns considering location by season and pen by season, respectively.

\section{Ammonia}

Nominally, barn F tended to show the highest ammonia concentrations at all monitoring locations, and barn $\mathrm{R}$ tended to show the lowest concentrations. There was an increasing concentration for locations in each barn based on proximity to the manure surface (fig. 7). The difference between seasons was also more apparent and significant closer to the manure and floor surfaces. Airflow patterns through slatted floors are challenging to measure, but theoretically the decrease in concentration between the manure and floor levels in barn F, in particular, suggests that gas may have built up under the slats because of low air transfer through the slatted floor. This reduces the influence on the cattle and worker area, but manure gas safety practices are needed when entering the manure pit, as with any manure storage system. At floor level and higher, the peak average concentration was $8.5 \mathrm{ppm}$, but all other averages were less than $5 \mathrm{ppm}$. The averages do not reflect the maximum peaks possible. Morrison et al. (1976) suspected that higher ammonia levels (aerial concentration not reported) and $27^{\circ} \mathrm{C}$ air temperature conditions contributed to reduced feed intake and rate of gain for cattle in mechanically ventilated rooms. For humans, the recommended time-weighted 8 $\mathrm{h}$ exposure level of ammonia is $25 \mathrm{ppm}$ (NIOSH, 2019). 
Table 8. Probability (p-values) for significant effects of factors for gas concentrations in three deep-pit beef cattle finishing barns. ${ }^{\text {[a] }}$

\begin{tabular}{|c|c|c|c|c|c|c|c|c|c|}
\hline \multirow{2}{*}{$\begin{array}{c}\text { Treatment } \\
\text { Effects }\end{array}$} & \multicolumn{3}{|c|}{ Ammonia } & \multicolumn{3}{|c|}{ Combined Sulfur } & \multicolumn{3}{|c|}{ Carbon Dioxide } \\
\hline & Barn F & Barn H & Barn R & Barn F & Barn $\mathrm{H}$ & Barn R & Barn F & Barn H & Barn R \\
\hline Pen & 0.1273 & 0.0003 & 0.6896 & 0.0057 & 0.518 & 0.9988 & 0.0021 & 0.0004 & 0.0001 \\
\hline Location & $<0.0001$ & $<0.0001$ & $<0.0001$ & $<0.0001$ & $<0.0001$ & 0.0308 & $<0.0001$ & $<0.0001$ & $<0.0001$ \\
\hline Pen $\times$ Location & 0.7997 & 0.2546 & 0.8366 & 0.8085 & 0.1035 & 0.9019 & 0.1536 & 0.9235 & 0.12 \\
\hline Season & $<0.0001$ & $<0.0001$ & $<0.0001$ & $<0.0001$ & $<0.0001$ & 0.0461 & $<0.0001$ & 0.0002 & $<0.0001$ \\
\hline Pen $\times$ Season & 0.3808 & 0.0041 & 0.0994 & 0.053 & 0.0006 & 0.3131 & 0.0156 & 0.8735 & 0.0364 \\
\hline Location $\times$ Season & $<0.0001$ & $<0.0001$ & 0.3082 & $<0.0001$ & 0.0002 & 0.5624 & $<0.0001$ & 0.0096 & 0.1032 \\
\hline
\end{tabular}

[a] Analysis based on lognormal-transformed gas concentration data.

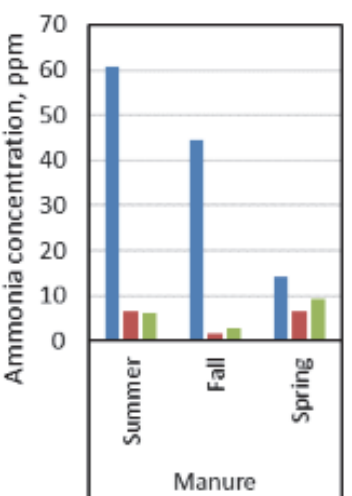

Location and Season

(a)

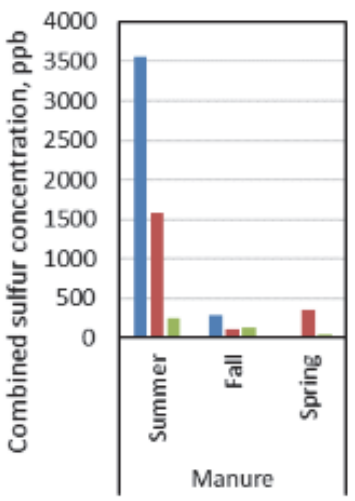

Location and Season

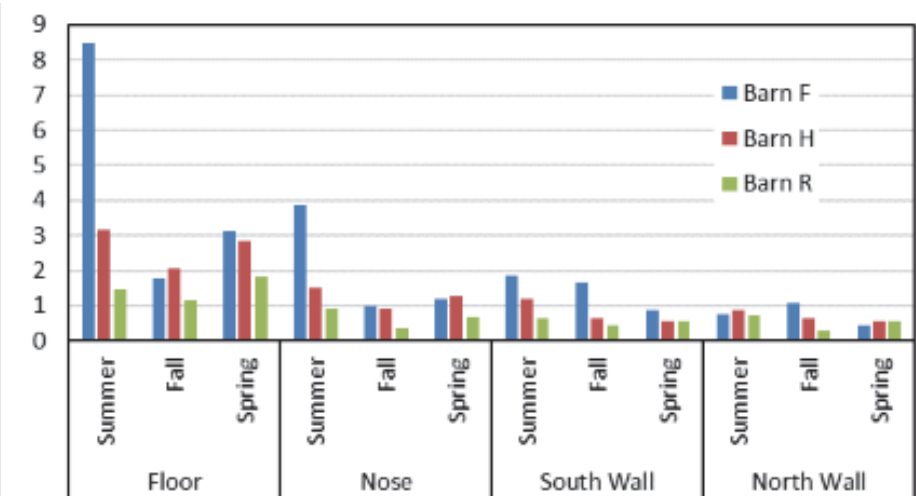

Location and Season

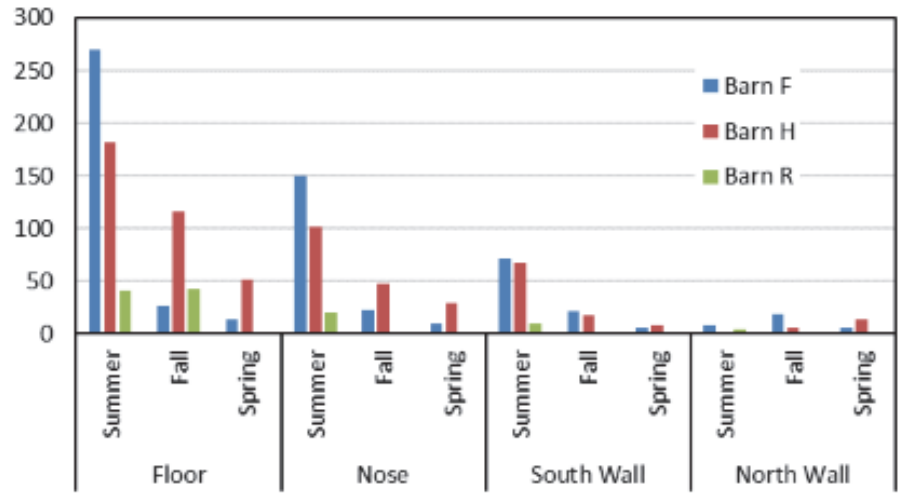

Location and Season

(c)

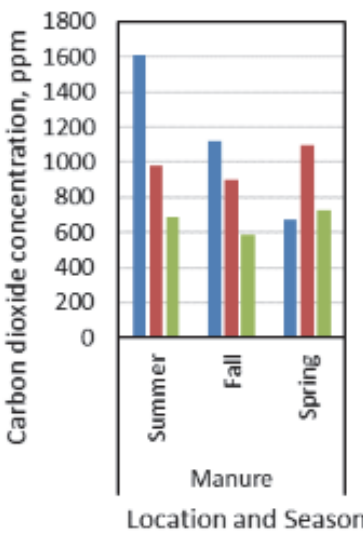

(e) (d)

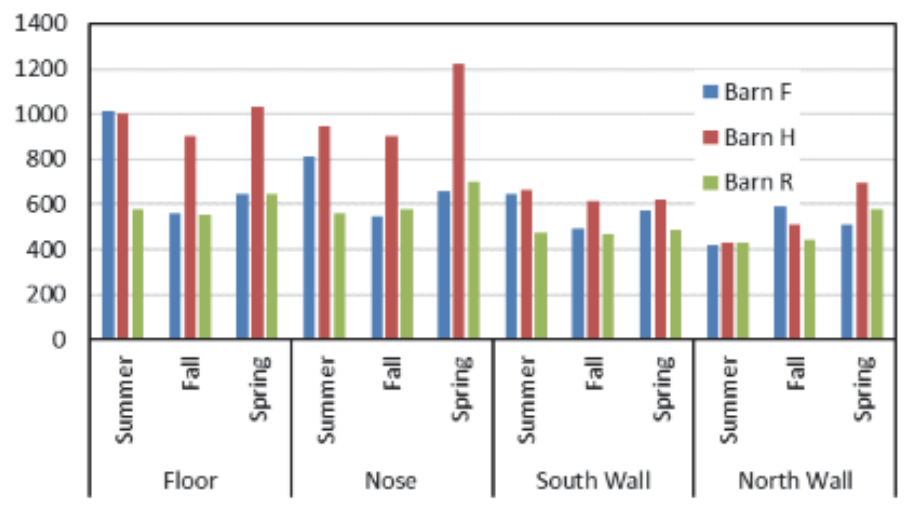

Location and Season

Figure 7. Average (a and b) ammonia, (c and d) combined sulfur, and (e and f) carbon dioxide concentrations by location of measurement and season for three deep-pit finishing beef cattle facilities. 
Pen by season differences were not significant for barn $\mathrm{F}$ and barn $\mathrm{R}$ (table 8), despite differences in cattle occupancy among pens between seasons. The interaction was significant for barn H. Barn H pens 2 and 13 shared a common manure pit and were in a semi-separated airspace from pens 6 and 9 (fig. 8). Cattle occupancy differed between pens and seasons, but there were always some cattle in each pen contributing fresh manure. Total nitrogen based on the agitated manure samples (table 5) was higher for the east pit relative to the west pit.
The primary source of ammonia is manure on the floor surface or in the manure pit. Higher source concentrations, warmer temperatures, and higher air speed across the surface increase ammonia volatilization (Montes et al., 2009; Ni, 1999). Ammonia concentration at the manure surface increases in response to increases in ammoniacal nitrogen concentration, $\mathrm{pH}$, and temperature. Figure 9a shows that the ammonium-N concentration in the manure can partially explain the higher aerial ammonia concentration levels. Figure $9 \mathrm{~b}$ shows that for all barns, aerial ammonia concentration levels tended to increase with higher seasonal temperatures.
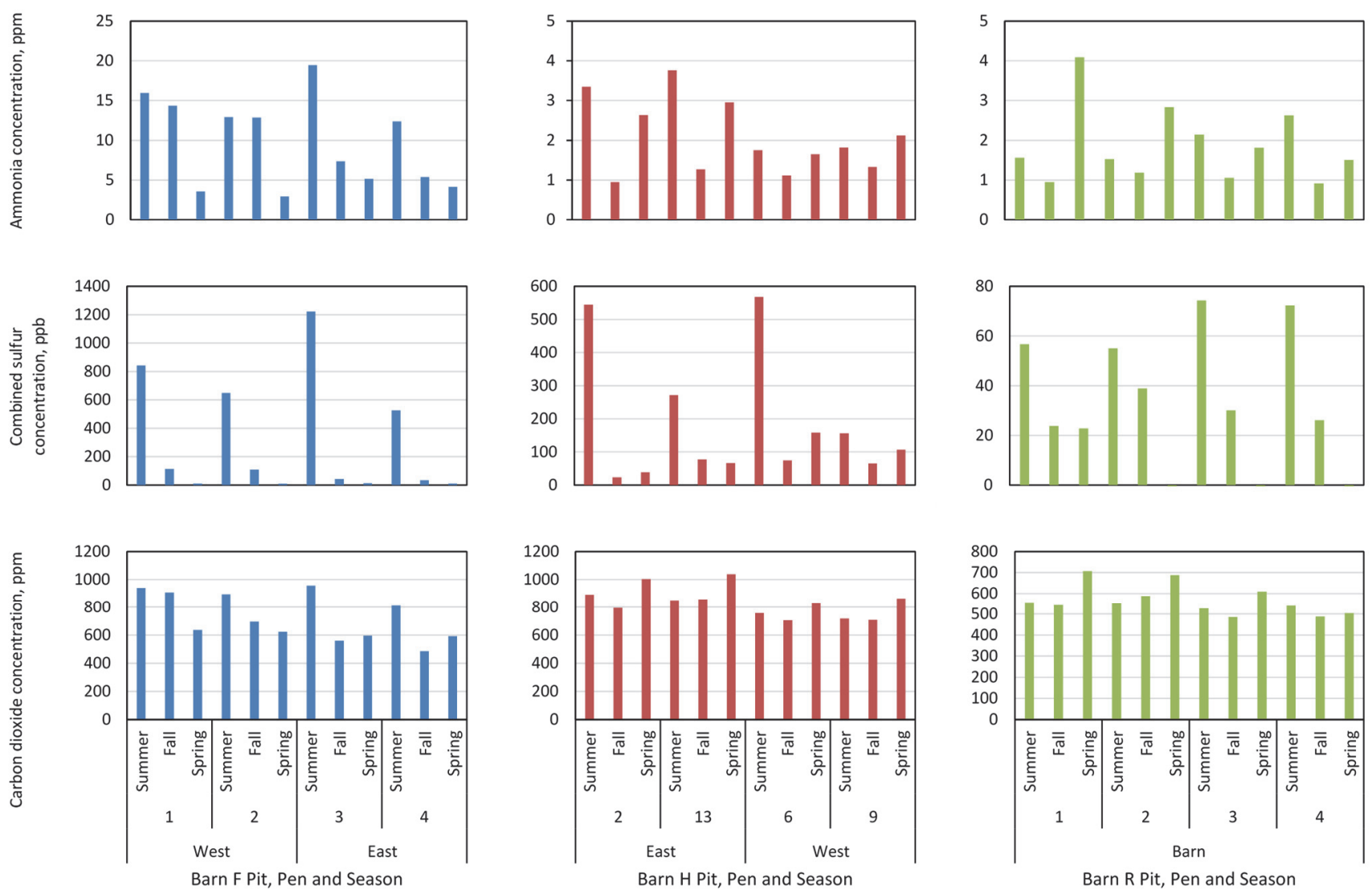

Figure 8. Average ammonia, combined sulfur, and carbon dioxide concentrations by barn, pen, and season for three deep-pit beef cattle barns.

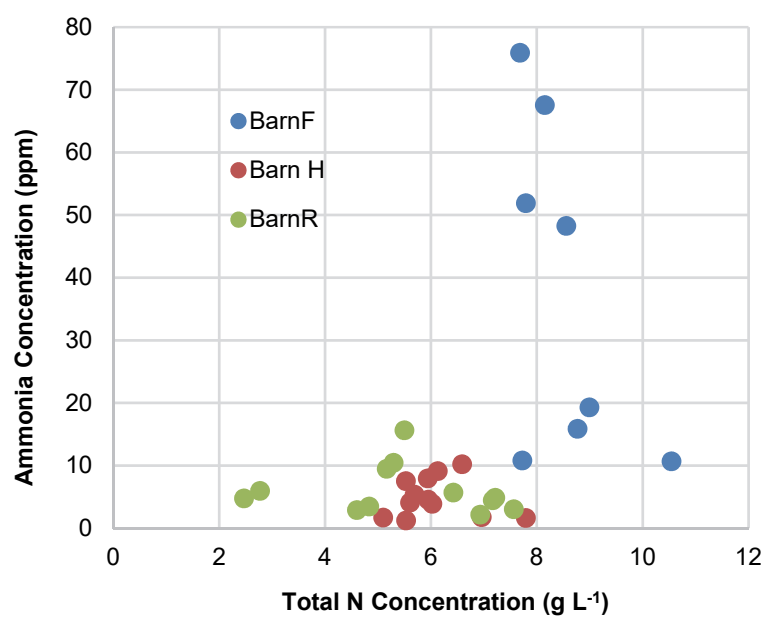

(a)

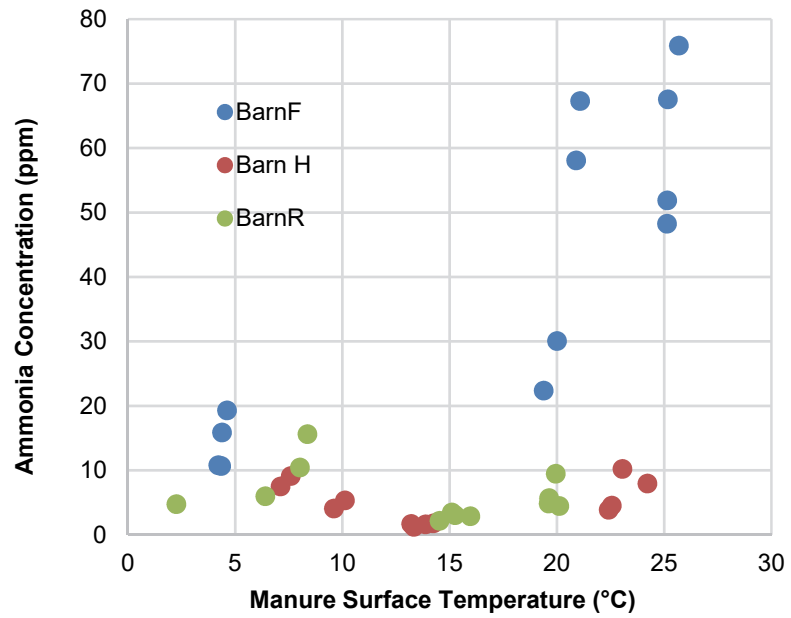

(b)

Figure 9. (a) Ammonia concentration above the manure surface for each pen and the corresponding manure ammonium-N concentration and (b) seasonal manure surface temperature. 
The ammonium- $\mathrm{N}$ concentration for barn $\mathrm{F}$ in the spring may have increased because of the low temperatures and volatilization. The $\mathrm{pH}$ was not measured, but as the most significant factor that determines the volatile portion of total ammoniacal nitrogen, it may be the missing piece.

\section{Combined Sulfur}

The significant factors for combined sulfur differences within each barn are similar to the factors for ammonia (table 5). The relative magnitudes of combined sulfur between barns and within each barn are also similar to ammonia. Warmer temperatures and proximity to manure produced higher combined sulfur concentrations. Ni et al. (2010) showed that average $\mathrm{SO}_{2}$ concentrations were $14 \%$ of combined sulfur for lab-based measurements above swine manure. This suggests that the majority of the combined sulfur was likely $\mathrm{H}_{2} \mathrm{~S}$. The average concentration levels above the manure surface peaked at $3500 \mathrm{ppb}$. The recommended $8 \mathrm{~h}$ time-weighted average exposure level for $\mathrm{H}_{2} \mathrm{~S}$ is $10,000 \mathrm{ppb}$ (NIOSH, 2015). The evidence of variable combined sulfur and $\mathrm{H}_{2} \mathrm{~S}$ above the stored manure reinforces the importance of manure gas safety practices when agitating and removing manure.

Recent (within a week) manure removals and/or transfers may explain the considerable drop in combined sulfur above the manure for barns $\mathrm{F}$ and $\mathrm{H}$ between the summer and fall seasons. Manure removal and/or transfer likely introduced oxygen into the manure system and temporarily slowed the anaerobic $\mathrm{H}_{2} \mathrm{~S}$ production. Additionally, variation in water quality (table 4), temperature conditions (table 6), and solids distribution in the manure (table 5) are all likely contributors to the variation in combined sulfur concentration levels between barns. Combined sulfur measurements were below the detection limit at barn $\mathrm{R}$ in the spring season for floor level and higher in the barn. The variation between pens (fig. 8) may also relate to the tendency for $\mathrm{H}_{2} \mathrm{~S}$ to be emitted in bursts when manure is disturbed (Ni et al., 2000). A urine or feces deposit may provide sufficient disturbance for small bursts of $\mathrm{H}_{2} \mathrm{~S}$ release.

\section{Carbon Dioxide}

The peak average $\mathrm{CO}_{2}$ location was the manure surface for barn $\mathrm{F}$ but nose level for barns $\mathrm{H}$ and $\mathrm{R}$ (fig. 7). There was generally less variation in $\mathrm{CO}_{2}$ concentrations between locations compared to ammonia and $\mathrm{H}_{2} \mathrm{~S}$, which was expected because of the contribution of $\mathrm{CO}_{2}$ by animal respiration in addition to manure generation. The difference between the north wall and south wall concentrations was up to $200 \mathrm{ppm}$, with the north and south walls altering ambient and exhaust conditions depending on the wind direction (fig. 7 and table 6). Ambient concentrations of 400 to $450 \mathrm{ppm}$ are consistent with the global average of $407.4 \mathrm{ppm}$ in 2018 (Lindsey, 2019). Carbon dioxide production by manure is often considered negligible relative to respired $\mathrm{CO}_{2}$ (Albright, 1990). However, $\mathrm{CO}_{2}$ production by stored swine manure was, on average, $37.5 \%$ of the respired $\mathrm{CO}_{2}$ by pigs in one study (Ni et al., 1999) and may also increase proportionally as the total solids content of the manure increases (Ni et al., 2010).
The pen by season interaction was significant for barns $\mathrm{F}$ and $\mathrm{R}$ (table 8), which had variable stocking densities between seasons. At barn F, the concentrations varied considerably from 800 to $950 \mathrm{ppm}$ between pens in the summer, but the variation did not follow a specific pattern with respect to wind direction (fig. 8). In the fall, average pen concentrations ranged from 900 to $550 \mathrm{ppm}$ for pens with and without cattle, respectively. Spring concentrations were consistent and lower than previous seasons, which may relate to temperature conditions or a strong south wind. Average pen concentrations in barn $\mathrm{R}$ were lowest for pens without cattle each season. Barn H pens always had some cattle, and average pen concentrations ranged between 700 and 900 ppm, with the exception of spring, when east side concentrations were closer to $1000 \mathrm{ppm}$.

\section{Volatile Organic Compounds}

Volatile organic compounds are produced from aerobic and anaerobic digestion of carbohydrates and proteins in livestock manure (Le et al., 2005; Mackie et al., 1998; Miller and Varel, 2001, 2002; Spoelstra, 1980). Of the compounds measured, phenols and indoles are most commonly associated with feedlot odors (Trabue et al., 2011). Phenol and 4ethyl phenol have human odor detection thresholds of 206 and $1.3 \mathrm{ng} \mathrm{L}^{-1}$, respectively, while indole and skatole have odor detection thresholds of 2.1 and $0.48 \mathrm{ng} \mathrm{L}^{-1}$, respectively (van Gemert, 2003). Overall concentrations of VOCs in the air from the deep-pit barns were quite low and well below the human detection thresholds for all of the compounds measured (table 9). The concentrations of dimethyldisulfide and dimethyltrisulfide were below the detection limits of the GCMS and are not included in table 9. When comparing the concentrations of VOCs at the nose level of cattle to the concentrations at the north wall, butyric acid, heptanoic acid, isobutryic acid, indole, and skatole were all significantly higher at the north wall compared to nose level. Typically, air samples collected closest to the source of VOCs yield the highest concentrations. Therefore, it was expected that the air samples collected at the nose level of the cattle in the pens would have higher concentrations of VOCs than the air samples collected at the north wall, although both locations had very low concentrations.

Among the three barns, barn $\mathrm{R}$ had higher concentrations of phenol and 4-ethyl phenol than the other two barns. Many factors can influence the concentrations of VOCs measured in a facility, including the temperature, humidity, and ventilation rate in the facility, how recently the manure pit was emptied, the number and size of animals, diet composition (especially diets high in protein), and nearby silage storage, to name a few. Research has consistently demonstrated that the concentrations of aromatic compounds increase as the manure ages (Miller and Varel, 2001, 2002; Spiehs et al., 2013, 2014). Barn R had two pens that were empty for most of the study. Those pens did not have cattle to contribute fresh urine and feces, creating a more aged manure composition in the pits. The air samples were collected midway in barn $\mathrm{R}$, between the full and empty pens, and it is possible the higher concentrations of phenol and 4-ethyl phenol from the aged manure in the nearby empty pits were detected. The protocol used to collect VOCs can detect the presence of 
Table 9. Concentration of volatile organic compounds (VOCs) from beef deep-pit barns by barn and locations within each barn.

\begin{tabular}{|c|c|c|c|c|c|c|c|}
\hline \multirow[b]{2}{*}{ VOC } & \multicolumn{3}{|c|}{ Location $\left(\right.$ ng L $\left.^{-1}\right)$} & \multicolumn{4}{|c|}{$\operatorname{Barn}\left(\text { ng L }{ }^{-1}\right)^{[a]}$} \\
\hline & North Wall & Nose Level & p-Value & Barn F & Barn $\mathrm{H}$ & Barn R & p-Value \\
\hline \multicolumn{8}{|c|}{ Short-chain fatty acids } \\
\hline Acetic & $0.019 \pm 0.014$ & $0.044 \pm 0.010$ & 0.1916 & $0.043 \pm 0.017$ & $0.051 \pm 0.013$ & $0.016 \pm 0.014$ & 0.1854 \\
\hline Butyric & $0.002 \pm 0.000$ & $0.001 \pm 0.000$ & 0.0458 & $0.002 \pm 0.000$ & $0.002 \pm 0.000$ & $0.002 \pm 0.000$ & 0.9606 \\
\hline Propionic & $0.012 \pm 0.002$ & $0.012 \pm 0.001$ & 0.8206 & $0.010 \pm 0.002$ & $0.014 \pm 0.002$ & $0.011 \pm 0.002$ & 0.1297 \\
\hline Valeric & $0.027 \pm 0.002$ & $0.023 \pm 0.001$ & 0.0752 & $0.022 \pm 0.002$ & $0.024 \pm 0.002$ & $0.025 \pm 0.002$ & 0.6335 \\
\hline Heptanoic & $0.041 \pm 0.006$ & $0.023 \pm 0.004$ & 0.0175 & $0.023 \pm 0.008$ & $0.036 \pm 0.006$ & $0.025 \pm 0.006$ & 0.3429 \\
\hline Hexanoic & $0.020 \pm 0.001$ & $0.018 \pm 0.001$ & 0.1745 & $0.021 \pm 0.002$ & $0.018 \pm 0.001$ & $0.018 \pm 0.001$ & 0.2485 \\
\hline Total SCFAs & $0.123 \pm 0.019$ & $0.122 \pm 0.013$ & 0.9555 & $0.121 \pm 0.020$ & $0.145 \pm 0.016$ & $0.096 \pm 0.017$ & 0.1226 \\
\hline \multicolumn{8}{|c|}{ Branched-chain fatty acids } \\
\hline Isobutyric & $0.008 \pm 0.00$ & $0.007 \pm 0.00$ & 0.0483 & $0.007 \pm 0.001$ & $0.007 \pm 0.000$ & $0.007 \pm 0.001$ & 0.7357 \\
\hline Isovaleric & $0.004 \pm 0.00$ & $0.007 \pm 0.00$ & 0.0864 & $0.004 \pm 0.002$ & $0.008 \pm 0.001$ & $0.005 \pm 0.001$ & 0.1158 \\
\hline Total BCFAs & $0.010 \pm 0.001$ & $0.008 \pm 0.000$ & 0.0473 & $0.008 \pm 0.001$ & $0.009 \pm 0.001$ & $0.009 \pm 0.001$ & 0.7963 \\
\hline \multicolumn{8}{|c|}{ Aromatic compounds } \\
\hline Phenol & $0.357 \pm 0.069$ & $0.379 \pm 0.047$ & 0.7696 & $0.628 \pm 0.046 \mathrm{a}$ & $0.351 \pm 0.036 b$ & $0.225 \pm 0.038 b$ & $<0.01$ \\
\hline 4-ethyl phenol & $0.002 \pm 0.000$ & $0.003 \pm 0.000$ & 0.0587 & $0.004 \pm 0.001 \mathrm{a}$ & $0.003 \pm 0.000 \mathrm{~b}$ & $0.002 \pm 0.000 \mathrm{~b}$ & $<0.01$ \\
\hline Indole & $0.004 \pm 0.000$ & $0.003 \pm 0.000$ & 0.0480 & $0.003 \pm 0.000$ & $0.003 \pm 0.000$ & $0.003 \pm 0.000$ & 0.6306 \\
\hline Skatole & $0.004 \pm 0.000$ & $0.003 \pm 0.000$ & 0.0497 & $0.004 \pm 0.000$ & $0.004 \pm 0.000$ & $0.004 \pm 0.000$ & 0.6669 \\
\hline Total aromatics & $0.367 \pm 0.069$ & $0.389 \pm 0.047$ & 0.7977 & $0.639 \pm 0.047 \mathrm{a}$ & $0.361 \pm 0.036 \mathrm{~b}$ & $0.235 \pm 0.038 \mathrm{c}$ & $<0.01$ \\
\hline
\end{tabular}

[a] Among barns, columns with different letters indicate significant differences at $\mathrm{p}<0.05$.

these compounds at levels much lower than the human nose can detect; we can conclude that the odors caused by the VOCs were minimal on our sampling dates and below the level of concern for humans in or near the barns.

\section{CONCLUSION}

Deep-pit cattle barns vary in design and management. In this study, environmental and air quality data collected from three deep-pit barns in Minnesota describe where and how conditions vary that can ultimately influence cattle health, performance, and environmental quality. The three farms differed in stocking practices, well water quality, and manure management. Feed rations were within expected ranges for finishing cattle. The manure composition in the deep-pit manure storages varied within barns and within common pits. When comparing surface and agitated manure sample composition, greater nutrients were typically present with greater solids or dry matter content. Total $\mathrm{N}$, ammonium-N, and phosphate concentrations were higher than reported in previous literature, emphasizing the need for timely manure samples to guide manure application decisions. Air temperatures at the barn perimeter and animal level usually agreed within $1^{\circ} \mathrm{C}$ of ambient conditions. Surface temperatures under the roof and at floor and manure level were higher than corresponding ambient air temperatures. The air temperatures at floor and manure level were lower than ambient, and the difference increased in hot weather. Air speeds through the barn openings were generally $40 \%$ of the ambient wind speed, while the air speed at animal level was generally 1 to $3 \mathrm{~m} \mathrm{~s}^{-1}$ for wind speeds from 1 to $8 \mathrm{~m} \mathrm{~s}^{-1}$. Ammonia and combined sulfur concentrations increased with proximity to the manure surface. At animal level, $10 \mathrm{ppm} \mathrm{NH}_{3}$ was the highest average ammonia concentration among the barns, and this occurred during hot weather. Carbon dioxide distributions were influenced by the number of cattle in the pen, as expected. Volatile organic compound concentrations at animal level in these deep-pit facilities were quite low and well below the human odor detection threshold for all of the compounds measured. This is the first dataset reporting air quality in production-scale slatted-floor barns for beef cattle and contributes to a body of knowledge that can be used to develop process-based models for estimating air emissions from cattle facilities.

\section{ACKNOWLEDGEMENTS}

This project was supported by the USDA National Institute of Food and Agriculture (NIFA) Research Award 201567020-23453. We appreciate the collaborating producers who let us collect data on their farms and provided production data and observations with us. We also acknowledge contributions by S. Niraula and C. Modderman (data collection assistance), S. Cortus (layout drawings), A. Kruger (sorbent tube preparation and analysis).

\section{REFERENCES}

Albright, L. D. (1990). Environment control for animals and plants. St. Joseph, MI: ASAE.

ASABE. (2014). D384.2: Manure production and characteristics. St. Joseph, MI: ASABE.

Asem-Hiablie, S., Rotz, C. A., Stout, R., \& Fisher, K. (2017). Management characteristics of beef cattle production in the western United States. Prof. Animal Sci., 33(4), 461-471. https://doi.org/10.15232/pas.2017-01618

Asem-Hiablie, S., Rotz, C. A., Stout, R., \& Place, S. (2018). Management characteristics of beef cattle production in the eastern United States. Prof. Animal Sci., 34(4), 311-325. https://doi.org/10.15232/pas.2018-01728

Asem-Hiablie, S., Rotz, C. A., Stout, R., \& Stackhouse-Lawson, K. (2016). Management characteristics of beef cattle production in the Northern Plains and Midwest regions of the United States. Prof. Animal Sci., 32(6), 736-749. https://doi.org/10.15232/pas.2016-01539

Asem-Hiablie, S., Rotz, C. A., Stout, R., Dillon, J., \& StackhouseLawson, K. (2015). Management characteristics of cow-calf, stocker, and finishing operations in Kansas, Oklahoma, and Texas. Prof. Animal Sci., 31(1), 1-10. https://doi.org/10.15232/pas.2014-01350

Balsdon, S. L., Williams, J. R., Southwood, N. J., Chadwick, D. R., Pain, B. F., \& Chambers, B. J. (2000). Ammonia fluxes from solid and liquid manure management systems for beef cattle and 
pigs. Proc. 9th Intl. Conf. on FAO ESCORENA Network on Recycling of Agricultural, Municipal, and Industrial Residues in Agriculture (pp. 6-9). Rome, Italy: United Nations FAO.

Cortus, E. L., Al Mamun, M. R., Spiehs, M. J., Ayadi, F. Y., Doran, B. E., Kohl, K. D., ... Nicolai, R. (2015). Site, environmental, and airflow characteristics for mono-slope beef cattle facilities in the northern Great Plains. Trans. ASABE, 58(1), 123-135. https://doi.org/10.13031/trans.58.10800

Cortus, E., Spiehs, M. J., Doran, B. E., Al Mamun, M. R., Ayadi, F. Y., Cortus, S. D., ... Nicolai, R. (2014). Ammonia and hydrogen sulfide concentration and emission patterns for mono-slope beef cattle facilities in the northern Great Plains. ASABE Paper No. 141897896. St. Joseph, MI: ASABE.

Gibb, D. J., McAllister, T. A., Huisma, C., \& Wiedmeier, R. D. (1998). Bunk attendance of feedlot cattle monitored with radio frequency technology. Canadian J. Animal Sci., 78(4), 707-710. https://doi.org/10.4141/A98-032

Johnston, G. (2015). 4 ways this cattle barn is paying off. Successful Farming (18 Aug. 2015). Retrieved from $\mathrm{https}$ ://www.agriculture.com/livestock/cattle/4-ways-this-cattlebarn-is-paying-off_276-ar49926

Jones, D., Doran, B. E., Euken, R., \& Shouse, S. (2013). Cattle feeding in monoslope and gable roof buildings. Ames, IA: Iowa State University.

Le, P. D., Aarnink, A. J., Ogink, N. W., Becker, P. M., \& Verstegen, M. W. (2005). Odour from animal production facilities: Its relationship to diet. Nutr. Res. Rev., 18(1), 3-30. https://doi.org/10.1079/Nrr200592

Li, C. S., Salas, W., Zhang, R. H., Krauter, C., Rotz, A., \& Mitloehner, F. (2012). Manure-DNDC: A biogeochemical process model for quantifying greenhouse gas and ammonia emissions from livestock manure systems. Nutr. Cycling Agroecosyst., 93(2), 163-200. https://doi.org/10.1007/s10705012-9507-z

Lindsey, R. (2019). Climate change: Atmospheric carbon dioxide. Washington, DC: NOAA. Retrieved from https://www.climate.gov/news-features/understandingclimate/climate-change-atmospheric-carbon-dioxide

Mackie, R. I., Stroot, P. G., \& Varel, V. H. (1998). Biochemical identification and biological origin of key odor components in livestock waste. J. Animal Sci., 76(5), 1331-1342. https://doi.org/10.2527/1998.7651331x

Miller, D. N., \& Varel, V. H. (2001). In vitro study of the biochemical origin and production limits of odorous compounds in cattle feedlots. J. Animal Sci., 79(12), 2949-2956. https://doi.org/10.2527/2001.79122949x

Miller, D. N., \& Varel, V. H. (2002). An in vitro study of manure composition on the biochemical origins, composition, and accumulation of odorous compounds in cattle feedlots. J. Animal Sci., 80(9), 2214-2222. https://doi.org/10.1093/ansci/80.9.2214

Montes, F., Rotz, C. A., \& Chaoui, H. (2009). Process modeling of ammonia volatilization from ammonium solution and manure surfaces: A review with recommended models. Trans. ASABE, 52(5), 1707-1719. https://doi.org/10.13031/2013.29133

Morrison, S. R., Lofgreen, G. P., \& Givens, R. L. (1976). Effect of ventilation rate of beef-cattle performance. Trans. ASAE, 19(3), 530-532. https://doi.org/10.13031/2013.36064

MWPS. (2004). Manure characteristics (2nd Ed.). MWPS-18-S1. Ames, IA: MidWest Plan Service.

NASEM. (2016). Nutrient requirements of beef cattle (8th Ed.). Washington, DC: National Academies Press.

Ngwabie, N. M., Jeppsson, K. H., Gustafsson, G., \& Nimmermark, S. (2011). Effects of animal activity and air temperature on methane and ammonia emissions from a naturally ventilated building for dairy cows. Atmos. Environ., 45(37), 6760-6768. https://doi.org/10.1016/j.atmosenv.2011.08.027
Ni, J. Q. (1999). Mechanistic models of ammonia release from liquid manure: A review. J. Agric. Eng. Res., 72(1), 1-17. https://doi.org/10.1006/jaer.1998.0342

Ni, J. Q., Heber, A. J., Diehl, C. A., \& Lim, T. T. (2000). Ammonia, hydrogen sulfide, and carbon dioxide release from pig manure in under-floor deep pits. J. Agric. Eng. Res., 77(1), 53-66.

Ni, J. Q., Vinckier, C., Hendriks, J., \& Coenegrachts, J. (1999). Production of carbon dioxide in a fattening pig house under field conditions: II. Release from the manure. Atmos. Environ., 33(22), 3697-3703. https://doi.org/10.1016/S13522310(99)00128-4

Ni, J., Heber, A. J., Sutton, A., Kelly, D. T., Patterson, J. A., \& Kim, S. (2010). Effect of swine manure dilution on ammonia, hydrogen sulfide, carbon dioxide, and sulfur dioxide releases. Sci. Total Environ., 408, 5917-5923. http://dx.doi.org/10.1016/j.scitotenv.2010.08.031

NIOSH. (2015). Hydrogen sulfide. In NIOSH pocket guide to chemical hazards. Washington, DC: NIOSH. Retrieved from http://www.cdc.gov/niosh/npg/npgd0337.html

NIOSH. (2019). Ammonia. In NIOSH pocket guide to chemical hazards. Washington, DC: NIOSH. Retrieved from https://www.cdc.gov/niosh/npg/npgd0028.html

Parker, D. B., Gilley, J., Woodbury, B., Kim, K. H., Galvin, G., Bartelt-Hunt, S. L., ... Snow, D. D. (2013). Odorous VOC emission following land application of swine manure slurry. Atmos. Environ., 66, 91-100.

https://doi.org/10.1016/j.atmosenv.2012.01.001

Peters, J. (2013). Lab procedures and methods. -Madison, WI: University of Wisconsin-Extension. Retrieved from https://uwlab.soils.wisc.edu/about-us/lab-procedures-andmethods/

Peterson, E. W., \& Hennessey, J. P. (1978). On the use of power laws for estimates of wind power potential. J. Appl. Meterol. Climatol., 17(3), 390-394. https://doi.org/10.1175/15200450(1978)017\%3C0390:OTUOPL\%3E2.0.CO;2

Philippe, F. A., Laitat, M., Canart, B., Vandenheede, M., \& Nicks, B. (2007). Comparison of ammonia and greenhouse gas emissions during the fattening of pigs kept either on fully slatted floor or on deep litter. Livestock Sci., 111(1-2), 144-152. https://doi.org/10.1016/j.livsci.2006.12.012

Ray, D. E., \& Roubicek, C. B. (1971). Behavior of feedlot cattle during two seasons. J. Animal Sci., 33(1), 72-76. https://doi.org/10.2527/jas1971.33172x

Rotz, C. A., Corson, M. S., Chianese, D. S., Montes, F., Hafner, S. D., \& Coiner, C. U. (2012). The Integrated Farm System Model: Reference Manual, Version 3. Washington, DC: USDA Agricultural Research Service.

Samuelson, K. L., Hubbert, M. E., Galyean, M. L., \& Loest, C. A. (2016). Nutritional recommendations of feedlot consulting nutritionists: The 2015 New Mexico State and Texas Tech University survey. J. Animal Sci., 94(6), 2648-2663. https://doi.org/10.2527/jas.2016-0282

Spiehs, M. J., Brown-Brandl, T. M., Berry, E. D., Wells, J. E., Parker, D. B., Miller, D. N., ... DiCostanzo, A. (2014). Use of wood-based materials in beef bedded manure packs: 2 . Effect on odorous volatile organic compounds, odor activity value, Escherichia coli, and nutrient concentrations. J. Environ. Qual., 43(4), 1195-1206. https://doi.org/10.2134/jeq2013.05.0165

Spiehs, M. J., Brown-Brandl, T. M., Parker, D. B., Miller, D. N., Berry, E. D., \& Wells, J. E. (2013). Effect of bedding materials on concentration of odorous compounds and Escherichia coli in beef cattle bedded manure packs. J. Environ. Qual., 42(1), 6575. https://doi.org/10.2134/jeq2012.0251

Spiehs, M. J., Woodbury, B. L., Doran, B. E., Eigenberg, R. A., Kohl, K. D., Varel, V. H., ... Wells, J. E. (2011). Environmental conditions in beef deep-bedded mono-slope facilities: A 
descriptive study. Trans. ASABE, 54(2), 663-673.

https://doi.org/10.13031/2013.36469

Spoelstra, S. F. (1980). Origin of objectionable odorous components in piggery wastes and the possibility of applying indicator components for studying odor development. Agric. Environ., 5(3), 241-260. https://doi.org/10.1016/0304-1131(80)90004-1

Sutton, A. L., Jones, D. D., Joern, B. C., \& Huber, D. M. (2001). Animal manure as a plant nutrient resource. West Lafayette. IN: Purdue University Extension. Retrieved from https://www.extension.purdue.edu/extmedia/ID/ID-101.html

Trabue, S., Scoggin, K., McConnell, L., Maghirang, R., Razote, E., \& Hatfield, J. (2011). Identifying and tracking key odorants from cattle feedlots. Atmos. Environ., 45(25), 4243-4251. https://doi.org/10.1016/j.atmosenv.2011.04.081

van Gemert, L. J. (2003). Odour thresholds: Compilations of odour thresholds in air, water, and other media. Zeist, Netherlands: Oliemans, Punter, and Partners.

Weather Spark. (2019). Average weather in Minnesota. Excelsior, $\mathrm{MN}$ : Cedar Lake Ventures, Inc. Retrieved from https://weatherspark.com/

Weather Underground. (2019). History. Retrieved from weatherunderground.com/history 